\title{
Root Cultures, a Boon for the Production of Valuable Compounds: A Comparative Review
}

\author{
Masooma Jawad Hussain ${ }^{1}{ }^{\circ}$, Yawar Abbas ${ }^{1}{ }^{\mathbb{D}}$, Naushaba Nazli ${ }^{1}$, Sara Fatima ${ }^{1}$, Samantha Drouet ${ }^{2}$, \\ Christophe Hano ${ }^{2}\left(\mathbb{D}\right.$ and Bilal Haider Abbasi ${ }^{1, *}$ (i)
}

1 Department of Biotechnology, Quaid-i-Azam University, Islamabad 45320, Pakistan; masoomajawad@bs.qau.edu.pk (M.J.H.); ayawar@bs.qau.edu.pk (Y.A.); naushabanazli@bs.qau.edu.pk (N.N.); sarafatima@bs.qau.edu.pk (S.F.)

2 Laboratoire de Biologie des Ligneux et des Grandes Cultures (LBLGC), University of Orleans, INRAE USC1328, F28000 Chartres, France; samantha.drouet@univ-orleans.fr (S.D.); hano@univ-orleans.fr (C.H.)

* Correspondence: bhabbasi@qau.edu.pk; Tel.: +92-51-90644121

Citation: Hussain, M.J.; Abbas, Y.; Nazli, N.; Fatima, S.; Drouet, S.;

Hano, C.; Abbasi, B.H. Root Cultures, a Boon for the Production of Valuable Compounds: A Comparative Review. Plants 2022, 11, 439. https://doi.org/ $10.3390 /$ plants 11030439

Academic Editor: Mauro Commisso

Received: 29 December 2021

Accepted: 27 January 2022

Published: 5 February 2022

Publisher's Note: MDPI stays neutral with regard to jurisdictional claims in published maps and institutional affiliations.

Copyright: (c) 2022 by the authors. Licensee MDPI, Basel, Switzerland. This article is an open access article distributed under the terms and conditions of the Creative Commons Attribution (CC BY) license (https:// creativecommons.org/licenses/by/ $4.0 /)$.

\begin{abstract}
Medicinal plants are an inevitable source of pharmaceutical drugs and most of the world population depends on these plants for health benefits. The increasing global demand for bioactive compounds from medicinal plants has posed a great threat to their existence due to overexploitation. Adventitious root and hairy root culture systems are an alternative approach to the conventional method for mass production of valuable compounds from medicinal plants owing to their rapid growth, biosynthetic and genetic stability. The main purpose of this review is to investigate the recent scientific research published worldwide on the application of adventitious and hairy root cultures to produce valuable compounds from medicinal plants. Furthermore, a comparison of adventitious root vs. hairy root cultures to produce valuable compounds has also been discussed. Various aspects such as medium composition, carbon source, $\mathrm{pH}$, amount of macronutrients, optimization strategy, scale-up cultures, and use of biotic abiotic and nano-elicitors at various concentrations are the topic of discussion in this review. Several studies on adventitious and hairy root cultures of Polygonum multiflorum, Withania somnifera, Echinacea purpurea and Ajuga bracteosa have been discussed in detail which highlights the importance of elicitation strategies and bioreactor system, presenting commercial applications.
\end{abstract}

Keywords: adventitious root culture; hairy root culture; medicinal plants; elicitation strategy; bioreactor

\section{Introduction}

Medicinal plants are an inevitable source of pharmaceutical drugs and most of the world population depends on these plants for their health. Plant cell and tissue cultivation to produce pharmaceutically important components of commercial interest have gained popularity over the last few years [1]. To save lives, humans have used medicinal plants as an endless source of drugs. In recent years plant cells, tissues or organs have increasingly been cultivated to get compounds that are both pharmaceutically and economically valuable [2]. After being isolated by solvent extraction from plants (that are grown normally) these compounds are then used as pharmaceuticals, nutraceuticals, pigments, foodstuffs, and cosmetics. Increasing requirements of secondary metabolites have diverted the attention towards cell culture technology to bring possible changes in secondary metabolism to produce bioactive molecules [3]. However, secondary metabolite production is suitable neither by cell culture nor from naturally grown plants. Major hurdles are higher content of water in cells, foaming, wall growth, and unstable production of metabolites in bioreactors [4]. In comparison, metabolite biosynthesis in naturally grown plants is affected by species or genus or might be activated just during a specific growth and developmental stage or by the availability of nutrients and pesticide contamination furthermore a great danger is imposed on the existence of plant species as these are continuously been 
destroyed for medicines [5]. Now, it is clear that for great socio-economic value other complementary techniques for complete plant cultivation should be developed to produce biologically valuable secondary metabolites. These are the reasons why efforts have been made in past years to develop plant cell, tissue, and organ culture as an alternative method to plant cultivation to produce secondary metabolites of elite pharmacological values [3].

Recent plant research advancements depict that to produce biologically active compounds, the cultivation of adventitious roots in a bioreactor is a great alternative to other methods. A greater rate of proliferation, enormous potentialities of accumulation, and stable production of important secondary metabolites result when adventitious roots are induced in phytohormone supplemented medium under sterile conditions [6]. Considering these issues for mass scale cultivation of adventitious roots by employing bioreactor technology is utilized to produce important plant-derived secondary metabolites. Monitoring of parameters such as $\mathrm{pH}$ temperature and the oxygen concentration in the bioreactor can be done; therefore, bioreactor culture system is better than a traditional tissue culture system [7]. The nutrient concentration can be adjusted, and nutrient uptake can also be increased by continuous medium circulation. Moreover, cost and time can be decreased by improving cell proliferation and regeneration rates, product quality can also be controlled, the product 3 can be free of pesticide contamination, and the product can be obtained all year round to meet the increasing global requirement [8]. Despite the great advantages of secondary metabolite production by plant cell cultures, only paclitaxel, shikonin, ginsenosides, and berberine have been produced on a commercial scale, and those process plants are located in the USA, Japan, South Korea, and China, respectively [9]. To produce immense quantities of the plant-derived bioactive molecules for use in a variety of human therapy and cosmetics, adventitious root culture using automated bioreactor technology of various medicinally important plants must be established.

In the present study, the establishment of adventitious and hairy root cultures for the production of valuable compounds, and the recent progress in secondary metabolite production, from medicinal plants, by employing various enhancement strategies have been discussed. Furthermore, highlights regarding the comparison of adventitious vs. hairy roots for the production of valuable compounds have also been mentioned.

\section{Adventitious Root Culture}

Roots are regarded as a part of great secondary metabolism in the whole plant because these are a good source for bioactive molecules, proteins, and a range of metabolites [10]. Recent advances in plant biotechnology enable us to culture plant cells, tissues, and organs instead of complete plants to produce valuable secondary metabolites [11]. Because the low productivity and instability of plant cultures and non-synthesis of few important compounds in undifferentiated cells, mass production of important bioactive molecules is considered commercially difficult by plant cell culture [12]. Keeping these issues in consideration, to produce pharmaceutical and nutraceutical secondary metabolites, the adventitious root culture in a large-scale bioreactor is regarded as a great approach.

In an appropriate phytohormone supplemented medium and aseptic conditions, adventitious roots displayed a greater growth rate and a more active secondary metabolism [13]. Additionally, these are suitable biological materials for good commercial production of great secondary metabolites without foreign genes under in vitro conditions. Adventitious roots displayed greater stability in their growing environment and produced a cosmic amount of secondary metabolites in intracellular spaces and it can be more easily extracted and can be cultivated in a phytohormone amended medium with less inoculum but a greater growth rate compared to cell cultures [14].

One of the major steps of in vitro propagation is adventitious root formation which is used for the cultivation of several plant crops, including medicinal plants. As a result of new advancements in propagation technology, large amounts of biologically important compounds, such as phenols, terpenoids, and alkaloids have been produced using plant cells, tissue, as well as organ cultures [15]. Adventitious root cultures are thought to be 
the most promising method for biomass production because of their increased growth rate and stable metabolites production [16]. For example, adventitious roots of many important medicinal plants cultivated by micropropagation showed increased biomass production, accumulation, and biologically active compounds production. Therefore, in vitro culture of adventitious roots has enormous potential to be developed on a large scale for the production of biologically active compounds. Furthermore, plant roots are the main raw materials used for herbal drug preparations, accounting for about $60 \%$ of herbal medicinal plants used in ethnomedicine. Because of its capability for micropropagation and germplasm preservation, an adventitious root culture is highly useful [17].

\section{Hairy Root Culture}

Hairy root cultures hold immense potential for the biosynthesis of various classes of influential secondary metabolites along with volatile organic compounds. The production of fine roots occurs when Agrobacterium rhizogenes inserts its T-DNA into the Ri plasmid to genetically transform the plant tissue. The main advantage of the hairy root culture method is that plant growth regulators do not require media supplementation because the inserted T-DNA contains the required genes for endogenous auxin production. Hairy roots are highly branched as they lack geotropism and can, therefore, grow faster than normal roots. In addition to the typical root metabolites, they also produce metabolites that are naturally secreted by aerial parts of the plants. Moreover, like any other cell culture technology, hairy roots are physiologically and biochemically stable. They display faster growth, spontaneous shoots generation, as well as chemical and morphological similarity to the roots of a wild-type plant. These properties make hairy root cultures extremely convenient for research and industry [18-21].

\section{Hairy Root vs. Adventitious Root Culture}

Nowadays, studies on the production of crucial bioactive compounds in hairy root culture are increasingly popular. Agrobacterium rhizogenes is an agent which is responsible to cause hairy roots in plants characterized by a higher growth rate and genetic stability [22]. Despite the high growth rate, biochemical and genetic stability exhibited by hairy roots, the secondary metabolites produced in hairy root liquid culture remain in the root tissues which affect the cell growth and pose difficulties in extraction during the downstream process. While adventitious root cultures release secondary metabolites into the culture medium which can be easily extracted [23].

Moreover, hairy root cultures produce complex structures, i.e., opine-like substrates which are toxic to mammalian cells, and due to the complexity of these structures, hairy roots are difficult to use as a crude extract, because of the high purification cost for opinelike structures [24]. Adventitious root culture is free from opine-like complex, toxic substrates, and provides the system to study the coordination between primary and secondary metabolism [25]. Figure 1 represents a brief comparison between adventitious and hairy root cultures and the process of their induction. 


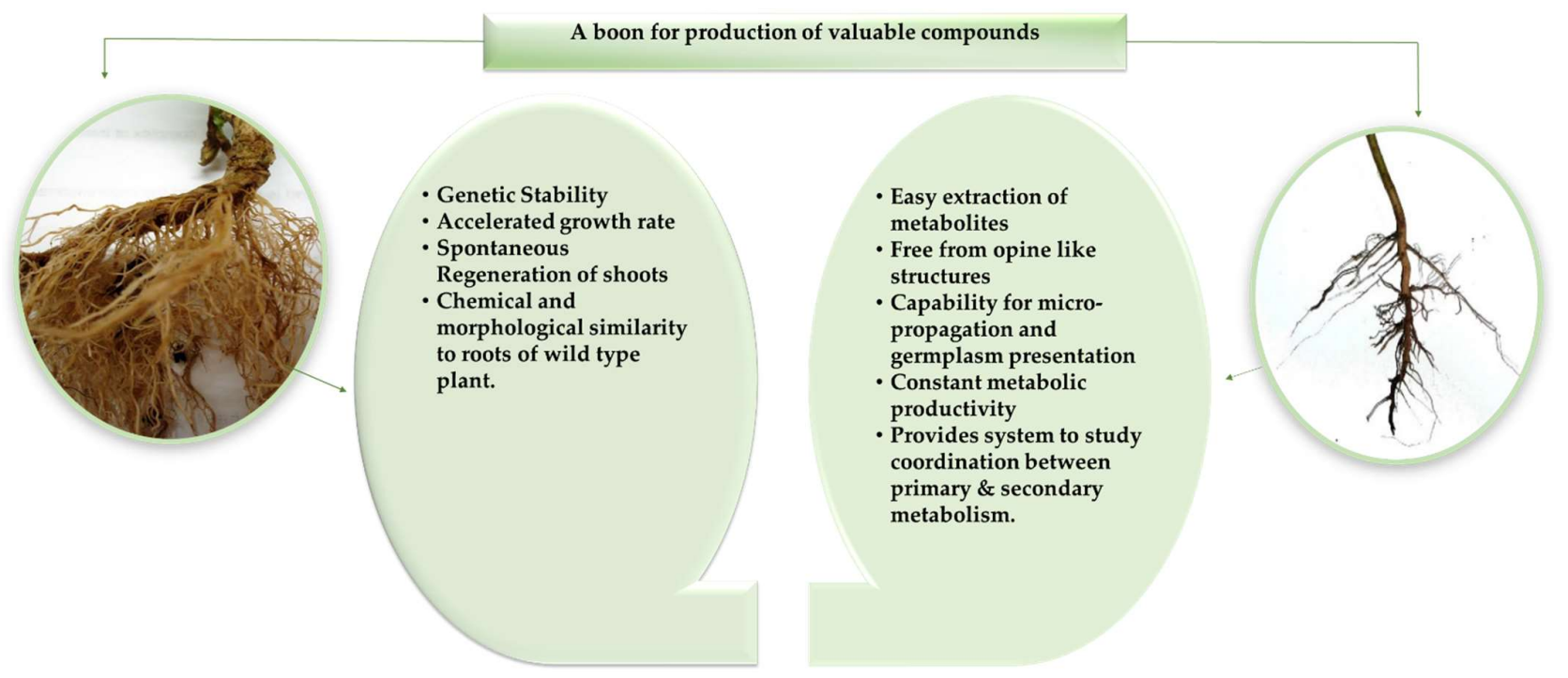

(a)
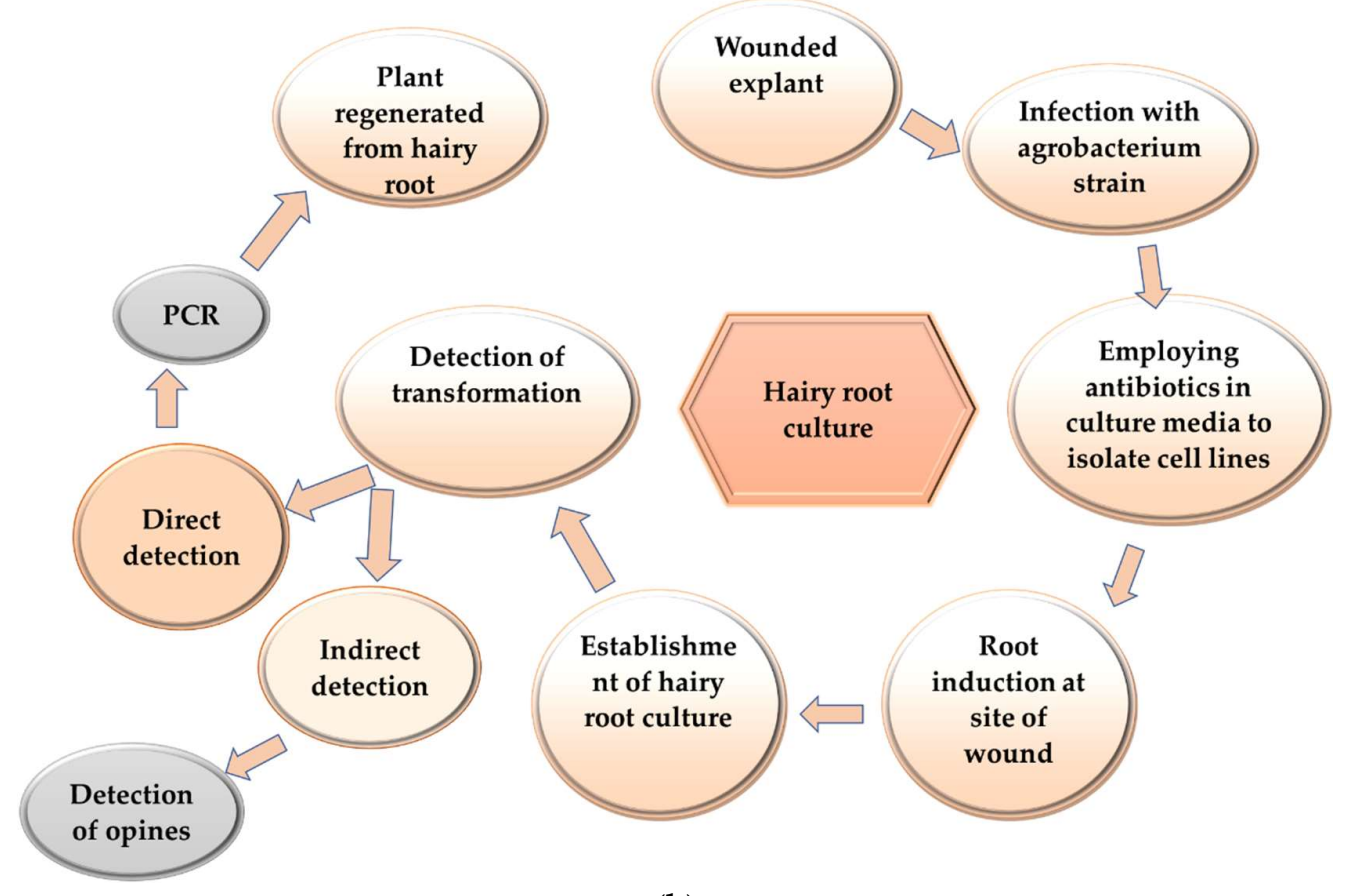

(b)

Figure 1. Cont. 


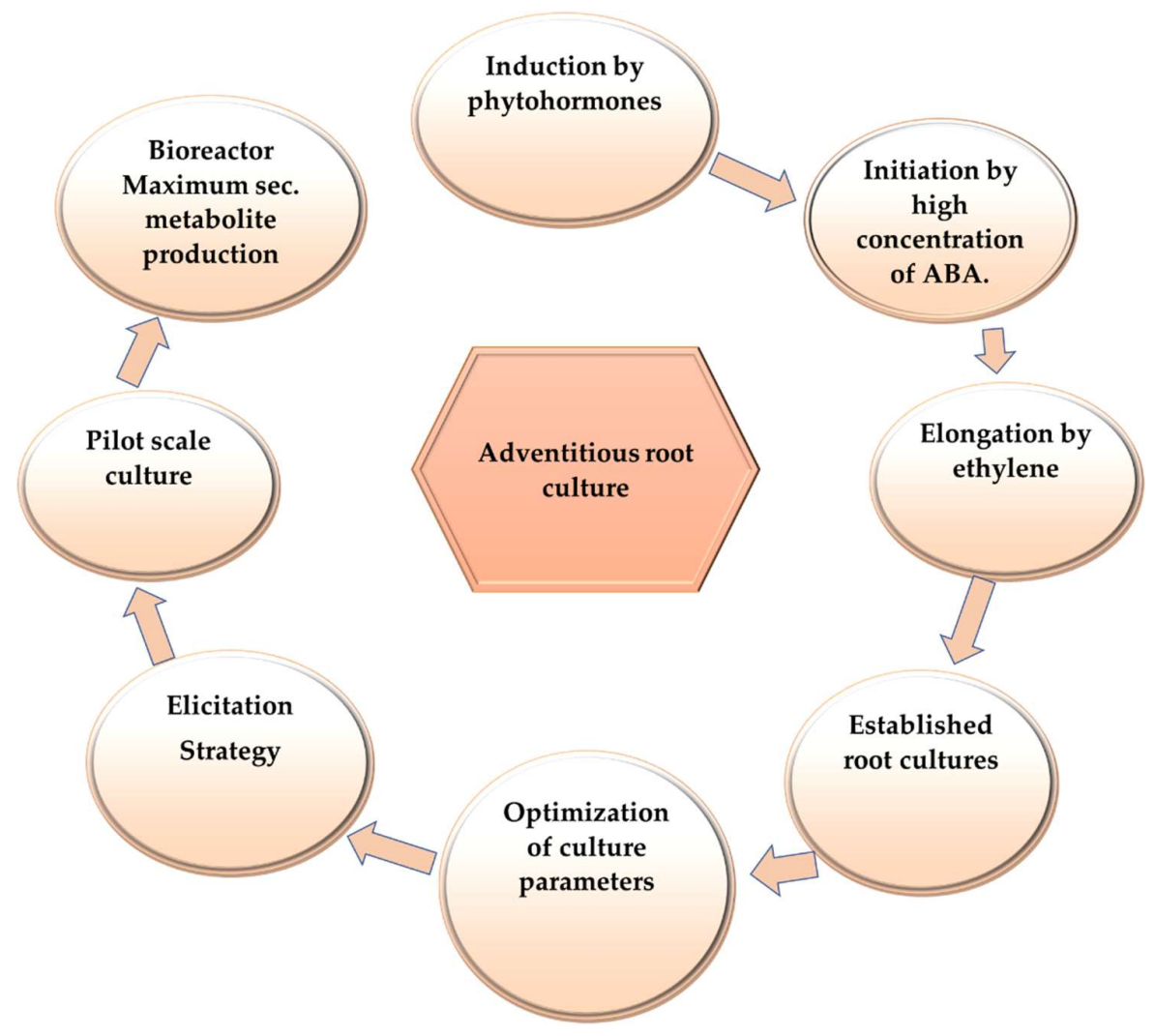

(c)

Figure 1. This figure shows a brief comparison between adventitious and hairy root culture and the process of their induction: (a) comparison between hairy root culture and adventitious root culture; (b) flowchart of hairy root induction; (c) flowchart of adventitious root culture.

\section{Media Properties and Culture Condition Effects}

Different factors influence the optimal growth of adventitious root culture of medicinal plants which include the type and strength of the media, the concentration of carbon source, $\mathrm{pH}$, and inoculum density. Various culture media have been used to optimize nutrient requirements [26]. Different types of media have different effects on the growth and development of adventitious roots grown in vitro to produce secondary metabolites. Furthermore, different properties of media such as media type, salt strength, sucrose composition, and $\mathrm{pH}$ have been studied in terms of the adventitious root culture of medicinal plants.

Ref. [27] reported that different culture media have different effects on induction and proliferation of adventitious root culture. Murashige and Skoog (MS) media were very effective for this purpose in culturing many medicinal plants $[28,29]$. The optimum conditions were achieved by changing concentrations of MS media, for example, full MS media was used for Boesenbergia rotunda and Vernonia amygdalina, whereas half MS medium was used for Camellia sinensis and Echinacea purpurea [30,31]. So, the most suitable culture media for the growth of the adventitious root of medicinal plants are greatly controlled by the plant species itself [32].

In addition to the media used, a different concentration of carbon sources is utilized by different species of medicinal plants, which shows that proper concentration of sucrose can induce the optimum growth of adventitious root biomass [33]. Ref. [27] reported that suitable concentrations of sucrose also increase the production of secondary metabolites. Osmotic agents like sorbitol and mannitol also affect the root dry weight and root growth was increased at $0.1 \mathrm{M}$ mannitol or sorbitol concentration [34]. $\mathrm{pH}$ is another factor that strongly influences plant tissue culture increasing biomass and secondary metabolites accumulation. Ref. [34] reported that root growth was at a higher peak at a $\mathrm{pH}$ range from 6.0 to 6.5 and strongly inhibited at $\mathrm{pH}$ below 4.0 or above 7.0. 


\section{Role of Plant Growth Regulator}

The rooting process can be stimulated by different hormones provided artificially and its physiological stages can be affected by changing the auxins concentration inside the roots [35]. Auxin, a plant hormone that comes from the amino acid tryptophan, controls many functions in cellular processes like growth, development, and proliferation of plant cells. The most widely used and naturally occurring auxins are indoleacetic acid (IAA) and indole-3-butyric acid (IBA). Along with natural auxins, different synthetic auxins have been synthesized, for example, 1-Naphthalene acetic acid (NAA) and 2,4-Dicholorophenoxacetic acid (2,4-D) [36].

Different types of auxins have different effects on the process of induction and proliferation of adventitious root culture. Of them, IBA is the most efficient type of auxins for the induction and proliferation of the adventitious root culture of medicinal plants [36]. The importance of auxins in root culture has been reported by many investigators. Auxin treatment strongly affects the root growth and depending on the concentration used, auxins either stimulate or inhibit the root production [37].

To determine the effect of growth regulators (auxins), adventitious roots were grown under different concentrations of indole-3-butyric acid (IBA) and 1-Naphthaleneacetic acid (NAA). By increasing the concentration of both IBA and NAA, root weight was increased and IBA was very effective as compared to NAA [38]. A higher concentration of auxins also decreases the rooting efficiency, because at high concentration auxins may become herbicides which prevent the induction of adventitious roots from explants [39].

Some investigators have reported that the effect of growth regulators on adventitious root growth differs from species to species. For example, [40] reported that in Gymnema sylvestre cells, NAA was very efficient as compared to IBA. Meanwhile, [41] reported that the dry mass produced from adventitious roots of Echinacea aungustifolia was the highest at IBA than the dry mass produced by NAA. Similarly, IBA was found more effective in adventitious root cultures of Panax ginseng compared to NAA [42]. Media that contains a large concentration of NAA encourage the formation of callus-like mass bodies characterized by short roots which produce low dry mass, whereas IBA is the most effective in induction and elongation of roots in Karwinskia calderonii root culture [43].

\section{Optimization Strategies to Improve Secondary Metabolite Production}

Recently, the production of secondary metabolites by using plant cell and tissue culture has become exciting new science. Several approaches are being routinely used by plant biotechnologists to improve secondary metabolite production by the selection of high producing cell lines, strain improvement, medium optimization, metabolic engineering, and elicitation as presented in Figure 2. One of the most important requirements is the in-depth knowledge of biosynthetic routes and mechanisms involved in the accumulation of secondary metabolites. The lack of knowledge of underlying mechanisms involved in the biosynthesis of useful secondary metabolites is the first barrier in developing commercial processes. One of the biggest challenges in the industrial application of plant cell, tissue, or organ culture for the efficient production of commercially relevant bioactive compounds has been stated to have a low product yield [44]. 


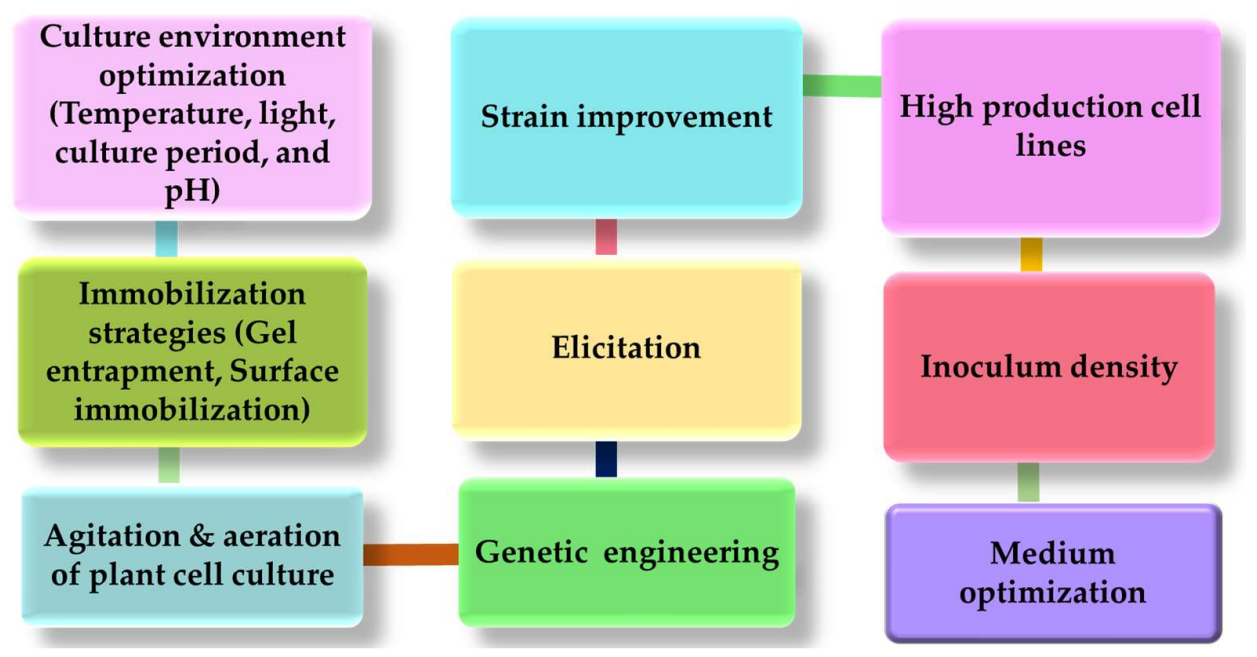

Figure 2. Optimization strategies to improve secondary metabolite production.

Several factors (chemical or physical) are being explored that may influence the production of secondary metabolites. Growth hormones often play a pivotal role in secondary metabolite production and accumulation in plants. For example, high auxin levels increase the growth of adventitious roots but may have a toxic effect on desired product formation. However, hairy root cultures induced by Agrobacterium rhizogenes tend to proliferate without the help of plant growth regulators. Other problems related to plant cell culture are their slow growth rates, high shear sensitivity, aggregates formation, and large size compared to microbial cells are responsible for a decrease in research and industrial exploitation.

Numerous approaches are being exploited that lead to the enhancement of secondary metabolite production in plants. Cell lines obtained from high-producing parent plants will also produce an elevated level of desired metabolites. The selection of storage or production cells is highly important as variable levels of production have been shown by different plant cells. Environmental factors such as sunlight, heat, $\mathrm{pH}$, and nutrient levels can also affect the level of secondary metabolite production. For example, the normal induction temperature range for callus culture is $17-25^{\circ} \mathrm{C}$, although each plant species may have a different optimum temperature. The extreme high and low $\mathrm{pH}$ can be toxic to plants hence medium $\mathrm{pH}$ is generally adjusted between 5-6 [45].

The intensity, quantity, and irradiation period of light have a considerable effect on plant growth and the production of secondary metabolites. Moderate light intensity has been shown to have a stimulatory effect on the production of some secondary metabolites like artemisinin in Artemisia annua, flavonoids [46], in Petroselinum hortense, and anthocyanins in Centaurea cyanus [47]. In some species, light is seen to have an inhibitory effect on the production of secondary metabolites such as monoterpenes in Citrus limon [48].

The growth, proliferation, and secondary metabolite accumulation of plant cells, tissues, and organ cultures can be affected by inoculum density. Relatively high inoculum density is used to initiate the cell suspension cultures because low densities often fail to initiate the growth. The inoculum size depends on the nutrient composition of the medium, the cell line, and other culture conditions. Medium conditioning is also a factor that can be used to minimize the inoculum density, but it has gained not much attention [49].

It has been suggested that developing special modeling systems can help researchers explore the growth features of in vitro cultures as well as the impact of culture conditions. In plant suspension cultures, the choice of culture medium, the use of appropriate nutrients, their ideal concentrations, and environmental conditions can all help to increase the yield and productivity of desired metabolites. The medium composition can be a crucial factor affecting metabolism and cell physiology. The most used medium for cell suspension culture is Gamborg's (B5), Linsmaier and Skoog (LS), and Murashige and Skoog (MS). However, it is critical to determine the optimum nutrient content and evaluate the impact 
of selected medium components on growth and product synthesis, as well as strike a balance. This is especially important for plant secondary metabolism because in some circumstances that are appropriate for plant growth can have a deleterious effect on the accumulation of desired product, and vice versa [50].

Genetic engineering is the combination of characteristics otherwise present in different plants and different cells in a single organism and the introduction of specified and active regulation mechanisms [45]. Metabolic engineering in plants can be achieved by elucidating the various pathways and genes encoding the regulatory proteins or metabolic enzymes to increase the production of the desired metabolite. Secondary metabolite accumulation can also be enhanced by blocking the unnecessary and competitive pathways [51].

The capacity of cultured plant cells to convert exogenously provided substances offers extensive potential towards the remodeling of natural and synthetic compounds. The capacity of cultured plants cells to enzymatically alter the molecules can be used in bioconversion processes. In plants, there are separate compartments for the synthesis and accumulation of secondary metabolites. The introduction of an additional artificial site for the storage of secondary metabolites can be a practical tool to enhance total metabolic production. Inhibition of negative feedback can also boost the accumulation of the desired metabolite.

Immobilization strategies can scale up the production of secondary metabolites by persistent process operation. Immobilization can easily overcome the problems associated with plant cell cultures such as low shear resistance and aggregate formation. With the advancements in immobilization techniques, a substantial increase has been seen in the number of applications of valuable secondary metabolites [52]. Gel entrapment and surface immobilization are the most used methods for cell immobilization in plant cells. The most widely used matrix in gel entrapment is gelation, agarose, calcium alginate, and polyacrylamide. The low shear sensitivity increases in secondary metabolite production, ease in downstream processing, low risk of contamination, and reduced cost are some of the major advantages associated with the immobilization of plant cells [53]. Agitation and aeration of plant cell cultures in large-scale bioreactors also play a crucial role in growth and secondary metabolite production. Although the agitation accelerates the culture growth by mass transfer, high shear stress can have harmful effects on cells viability. The shear sensitivity of plant cells restricts the use of high agitation speed that can otherwise prevent aggregate formation. Stirred tank bioreactor and bubble column bioreactors are most used for plant cell cultures to overcome rheological problems [25]. Aeration plays a significant role in oxygen transfer and maintenance of aerobic conditions in plant cell cultures. Although the oxygen need of plant cells is low due to their slow respiratory rates, oxygen supply can have a significant effect on the secondary metabolite accumulation as well as the growth of the plant [54].

\section{Elicitation}

The basis of elicitation lies in plant defense mechanisms. Any threat posed to plant either by pathogenic attack or biotic and abiotic stress will result in secondary metabolite production. Any factor either environmental or biological that has the ability to induce secondary metabolism in the plant is known as an elicitor [55].

Elicitors are compounds from various biotic or abiotic sources that can activate signal transduction pathways, which may enhance secondary metabolism in plant cells. Signal detection of the elicitor by a cell surface receptor is required for elicitor-mediated defensive responses [55]. Following that, some significant cellular and molecular events are transduced, culminating in the stimulation of gene expressions that lead to the synthesis of numerous proteins related to plant defensive responses as well as secondary metabolite synthesis and accumulation [55]. For instance, low molecular weight antimicrobial compounds are produced because of elicitation posed by pathogenic microbes.

Elicitors can be exogenous or endogenous factors that can trigger the production of secondary metabolites. The endogenous or biological elicitors include glycoproteins, organic acids, and membrane polysaccharides such as cellulose, pectin, glucans, chitosan, 
etc., while the exogenous Elicitors consist of heavy metals, $\mathrm{pH}$ and temperature, intensity and duration of light, and nutrients in culture medium. The secondary metabolism in plants can be induced by physical components such as osmotic shock, water stress, ultraviolet (UV) radiation and ozone, etc. [56]. Upon elicitation, by any of these compounds a cascade of reactions is originated, that activates the plant's innate immune system. To mediate the defense response, the plant signaling compounds such as nitric oxide, salicylic acid, and methyl jasmonate play an important role.

The mechanism of elicitation involves thousands of intertwined events that make it very complex. The elicitation mechanism varies in accordance with the available nutrients, stages of the cell cycle, type and concentration of elicitor, and physicochemical environment of the plant [57]. The first step of elicitation is signal recognition by binding of elicitor to its corresponding receptor on the plasma membrane. This will initiate the cascade of events such as ion flux, ROS outburst, G protein activation, etc. [58]. The activated/phosphorylated proteins will eventually stimulate the expression of genes that are involved in the pathways of secondary metabolites production [59].

Jasmonic acid (JA)-induced production of terpenoid indole alkaloids is one of the best-studied examples of elicitor-mediated secondary metabolite induction in hairy root culture [60]. The JA and related chemicals also serve as elicitor signal transducers for the manufacture of a variety of secondary metabolites, including alkaloids. For alkaloid biosynthesis, where jasmonates work by coordinating the expression of several biosynthetic genes, the effect of jasmonates on secondary metabolism has been examined in depth. Figure 3 represents the different types of elicitors used as a powerful means to improve the production of high-value compounds.

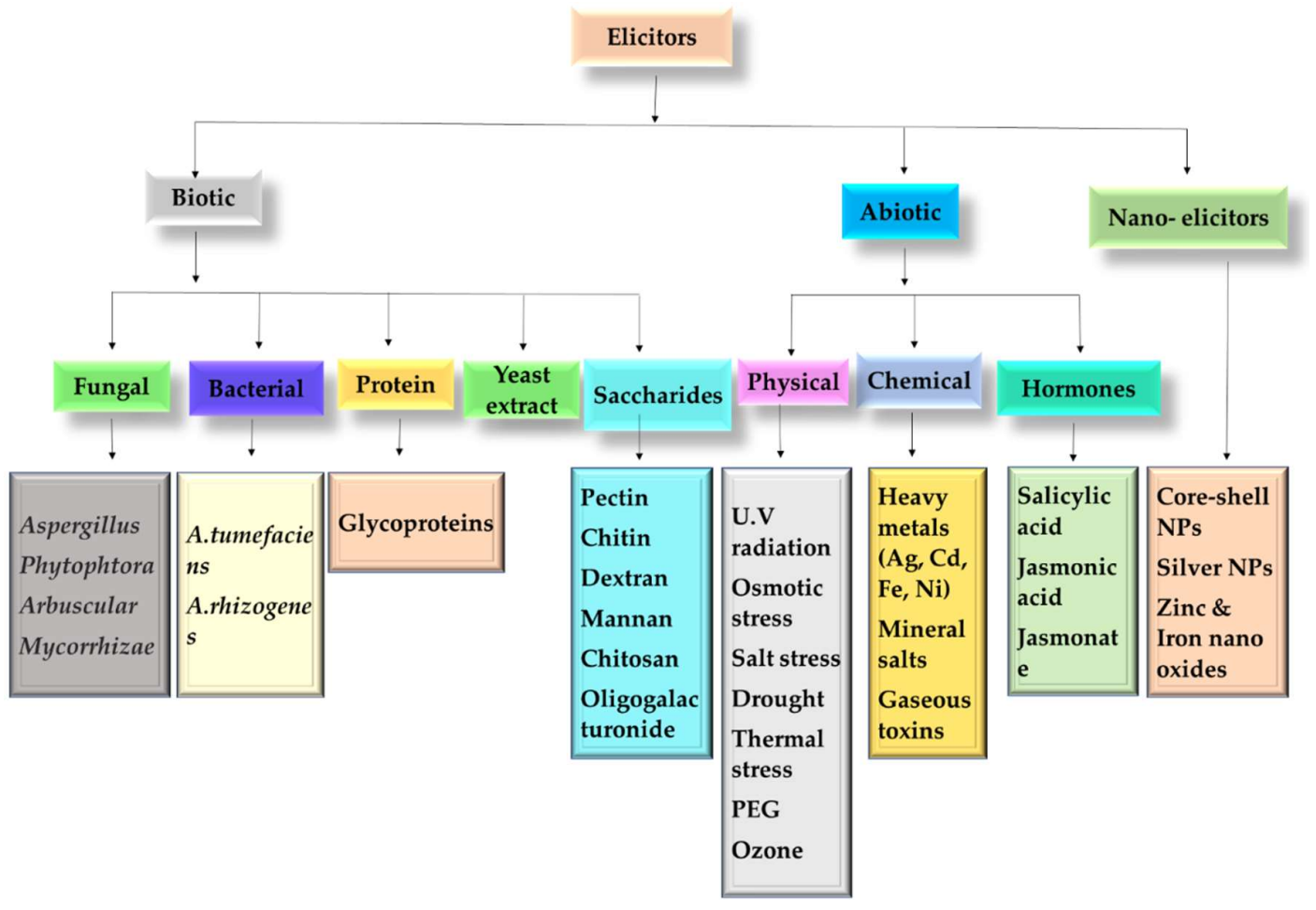

Figure 3. Elicitation, as a powerful means to improve the production of high-valued compounds.

\subsection{Biotic Elicitors}

There are various compounds that originate from living organisms either bacteria, viruses, and fungi, or from the plant itself that can enhance the production of secondary metabolites are known as biotic elicitors. The most used biotic elicitors are proteins, carbohydrates, fungi and plant growth-promoting bacteria, etc. [61]. The proteins enhance the secondary metabolite production by modulating the regulation of ion fluxes on plasma 
membrane ion channels in response to some external stimuli. For example, in plant cell cultures glycoprotein can enhance the production of phytoalexin. Carbohydrates have been associated with the elicitation of many secondary metabolites such as phytoalexins accumulation in cotyledons can be enhanced by Oligogalacturonides (OGAs) [62]. Plant growth-promoting rhizobacteria (PGPR) are also known to stimulate to biosynthetic pathways of many useful secondary metabolites such as jasmonic acid in plants [63]. Salicylic acid and jasmonic acid are the most common plant hormone that is used as elicitors in plants.

\subsection{Abiotic Elicitors}

The physical and chemical elicitors that have non-biological origins are known as abiotic elicitors. Abiotic elicitors have been successfully used at different growth stages to stimulate the production of plant phytochemicals. The most employed abiotic elicitors include temperature stress, heavy metals, light intensity, salinity, drought, etc. Heavy metals such as $\mathrm{Ag}, \mathrm{Cd}, \mathrm{Fe}$, and $\mathrm{Ni}$ can stimulate the accumulation of secondary metabolites by modulating their biosynthetic pathways [64]. Light has a stimulatory effect on many secondary metabolites production such as zingiberene and gingerol in Zingiber Officinale [65]. The field-grown plant also showed an increased accumulation of phenolic compounds and essential oils when exposed to UV radiations [66]. Elevated temperature can cause leaf senescence while increasing the secondary metabolite production in the roots of Panax quinquefolius. In some plants, cold temperatures can elicit secondary metabolite production such as sorbitol, inositol, raffinose, and saccharose are produced as cryoprotectant compounds in extreme winters [67]. Water deficiency or drought is a type of physical elicitor that can increase the secondary metabolites production in plants by modulating their biochemical and physiological properties [68]. Salicylic acid is known to stimulate the expression of defense genes and thus increase plant resistance against diseased pathogens [69], while jasmonic acid acts as an effective elicitor for the synthesis of many useful secondary metabolites such as flavonoids, terpenes, and alkaloids, etc.

\subsection{Nano-Elicitors}

Recently, nanoparticles are being explored as an emerging new class of elicitors. Some of the recent studies have shown the promising potential of nano elicitors in the induction of secondary metabolites accumulation in plant cell cultures. For example, elicitation with core-shell silver nanoparticles has shown an increased production of artemisinin in the hairy root culture of Artemisia annua [70]. A decrease in anthocyanin and flavonoid contents and an increase in carotenoid and saponin contents were shown in Calendula Officinalis upon elicitation by silver nanoparticles [71]. Zn and Fe nano-oxides have been reported to stimulate hypericin and hyperforin production in cell suspension cultures of H. perforatum [72]. Along with the use of metallic nanoparticles as nano elicitors, biotic elicitors such as Methyl Jasmonate, jasmonic acid, etc. can be explored as nanoparticles by encapsulating them into biodegradable polymers which can increase the production of secondary metabolites without affecting the growth of the plant [73]. Some studies also reported the increased productivity of nutraceuticals and the nutritional quantity of crops by the applications of nanotechnology. For instance, aloin is the most important secondary metabolite of aloe vera that has many important properties like antibacterial, antifungal, and antimalarial. Elicitation with abiotic nanoparticles $\mathrm{NH}_{4} \mathrm{NO}_{3}$ can increase the production of aloin up to $127 \%$ [73].

\section{Scale-Up of Culture Process}

The demand for plant secondary metabolites is increasing day by day due to their vast array of applications in the health and pharmaceutical industry. To achieve this rising demand of the global market, it is necessary to produce them on large scale. The bioreactor technology is the best alternative for growing plants conventionally to scale up the production of plant secondary metabolites [74]. The cultivation of plant cell cultures in 
large-scale bioreactors is more profitable and feasible as we can control the entire process to produce high-quality yields in bulk quantities [74].

The primary challenge in commercializing plant-derived secondary metabolites is scaling up the culture in a large-scale bioreactor. Because when cultures are transferred from shake flasks to bioreactors and then scaled up from pilot to industrial size, the environment in which plant cells and roots are cultivated might be changed. Due to this shifting effect of shear stress, oxygen supply, and gas composition in bioreactors reduced productivity has been observed [74,75].

The area of plant cell fermentation and scaling-up has received a lot of attention in recent decades. Plant cells are currently being cultured in amounts up to 75,000 L, and specialized bioreactor systems and effective plant cell culture systems have been developed for growing plant cells [76]. Despite many reports, only a few commercially effective experiments for the generation of adventitious root biomass and bioactive chemicals at industrial scale reactors have been reported. Ref. [77] scaled-up ginseng adventitious root culture in a $500 \mathrm{~L}$ balloon-type bubble bioreactor (BTBB), while [8] scaled up ginseng adventitious root culture in a 10,000 L BTBB.

The induction of adventitious roots from selected explants, as well as the optimization of process parameters, are all involved in scaling up adventitious root culture for the generation of biomass and secondary metabolites. Studies are being carried out on the growth kinetics and exploring suitable techniques for higher metabolite accumulation without affecting root growth, and cultivation of adventitious roots in pilot-scale bioreactors. High sparge rates may remove carbon dioxide and other nutrients from the culture media, depending on the metabolic activity of the cells. In these instances, the air-lift bioreactor is the most suitable reactor choice to effectively culture the suspension cells or roots [78].

\section{Case Studies}

\subsection{Polygonum multiflorum}

Polygonum multiflorum Thunb. (Polygonaceae), also known in the East as "He-ShouWu" and in the West as "Fo-ti", is one of the most important and commonly used traditional Chinese medicines (TCM) in therapeutic practice [79]. It is a popular Southeast Asian medicinal herb with high levels of phenolic components such as stilbenes, flavonoids, tannin, anthraquinones, and phospholipids, which are responsible for its pharmacological and antioxidant activities [80,81]. In China, Korea, and Japan, the root extracts of this herb were traditionally used as a hair dye, a liver and kidney tonic, and an anti-aging agent [82]. The plant has been used to treat coronary heart disease, hyperlipidemia, and neurosis, as well as aging-related disorders [83].

The increased demand for this plant has recently resulted in overexploitation of natural habitat yet; the bioactive components in Polygonum multiflorum roots are unstable in the natural setting. Field production has several limitations, including low yields, slow growth cycles, and quality and quantity changes caused by severe environmental, seasonal, and geographic factors [81]. Apart from advancements in plant cell culture, recent results in large-scale bioreactor synthesis of various plant secondary metabolites using adventitious root culture appear to be a promising strategy [8].

As a result, adventitious root cultures in bioreactors are recognized for their rapid growth and stable metabolic profiles that are comparable to those of field-grown plants $[84,85]$. In a $500 \mathrm{~L}$ pilot-scale bioreactor, an optimal yield of $4.01 \mathrm{~kg}$ dry root biomass and $287.12 \mathrm{mg} / \mathrm{L}$ total phenolic productivity of Polygonum multiflorum was attained [86]. In the study, [87] investigated the effects of several auxins on Polygonum multiflorum Thunb. Adventitious root cultures in a $3 \mathrm{~L}$ balloon-type bubble bioreactor (BTBB). IBA $(1,2$, and $4 \mathrm{mg} / \mathrm{L})$ promoted root development more effectively than NAA. Low MS salt strength $(0.25$ and 0.5X MS) enhanced total phenolics and flavonoids accumulation but decreased biomass accumulation. The maximum root biomass was obtained after four weeks of culture in full-strength MS medium supplemented with $2 \mathrm{mg} / \mathrm{L}$ IBA and 5\% sucrose [98.46 g/L fresh 
weight (FW); $13.46 \mathrm{~g} / \mathrm{L}$ (dry weight) and the accumulation of bioactive substances (total phenolic compounds, $53.08 \mathrm{mg} / \mathrm{g}$ dry weight; total flavonoids, $25.10 \mathrm{mg} / \mathrm{g}$ dry weight).

The effects of abiotic (methyl jasmonate) and biotic (yeast extract and chitosan) elicitors on adventitious root cultures of Polygonum multiflorum for improving bioactive component synthesis were examined. In comparison to the control, yeast extract resulted in considerably increased dry root biomass $(9.98 \mathrm{~g} / \mathrm{L})$ and relative growth rate $(p \leq 0.05)$. Abiotic elicitor-treated cultures had a larger percentage of dry weight than the other samples. MeJA had much better elicitation efficiency than the other treatments, according to HPLC analysis of several bioactive compounds. Under 50 molar MeJA treatments root dry weight increased by almost 2 -fold ( $22.08 \mathrm{mg} / \mathrm{g}$ dry weight) compared to the control (10.35 mg/g dry weight) [88].

Hairy root culture is another choice for the enhanced production of secondary metabolites. At 20 days, hairy roots cultured on MS liquid medium supplemented with $30 \mathrm{~g} / \mathrm{L}$ sucrose showed the maximum accumulation of biomass $(99.05 \mathrm{~g} / \mathrm{L}$ FW [fresh weight] and $10.95 \mathrm{~g} / \mathrm{L}$ dry weight) as well as the highest production of anthraquinones (emodin $211.32 \mu \mathrm{g} / \mathrm{g}$ dry weight and physcion $353.23 \mu \mathrm{g} / \mathrm{g}$ dry weight). When compared to the untransformed control root, suspension cultures produced a nearly 9.5 -fold increase in biomass after 20 days of culture, while hairy root biomass produced in suspension cultures had 3.7- and 3.5-fold higher levels of emodin and physcion, respectively [89]. Hairy root culture of Polygonum multiflorum produced root biomass $(105.2 \mathrm{~g} / \mathrm{L}$ of FW, $9.7 \mathrm{~g} / \mathrm{L}$ of dry weight), which is 10 -fold more than non-transgenic roots. It also increased total phenolic content $(26.64 \mathrm{mg} / \mathrm{g}$ dry weight), whereas non-transgenic roots accumulated $8.36 \mathrm{mg} / \mathrm{g}$ dry weight. Following exposure to 50 molar methyl jasmonate for 5 days the level of phenolic compounds in HRCs increased by more than 2.5 -fold.

Ref. [90], used co-cultivation of plant material with Agrobacterium rhizogenes strain LBA942 to induce transformed roots (hairy root) in Polygonum multiflorum and investigated the effects of exogenous phytohormones on hairy root growth and anthraquinone biosynthesis in hairy root suspension cultures. They discovered that 2,4-D inhibited hairy root growth and anthraquinone biosynthesis and that NAA and BAP supplementation aided hairy root growth and anthraquinone accumulation. To produce hairy roots in $P$. multiflorum, A. rhizogenes R1601 was used. Murashige Skoog (MS), 1/2 MS and B5, were tested to see which combination was best for the culture medium. For hairy root growth, MS medium was the best of the four media. Meanwhile, the hairy roots growth kinetics and nutrient consumption findings revealed that they had a sigmoidal curve and that the best inoculation period for them was 18-21 days. The analysis of the anthraquinone component shown that the hairy roots had a rhein concentration of $2.495 \mathrm{~g} / \mathrm{g}$, which was 2.55 times greater than that of natural plants [91].

The above study suggests that adventitious root culture in a bioreactor system with an elicitor is a good alternative strategy to hairy root culture for large-scale production of $P$. multiflorum adventitious roots with high biomass and bioactive compounds accumulation.

\subsection{Withania somnifera}

Withania somnifera (L.) Dunal, commonly known as ashwagandha, Indian ginseng, or winter cherry, is a tomentose evergreen shrub of the family Solanaceae [92]. It is widely distributed in Asia, Africa, the Mediterranean region, and the Middle East, apart from India [93]. More than 200 primary and secondary metabolic components of withania somnifera have been studied in multiple investigations. The importance of Withania in the medicinal world has been acknowledged due to its maximum accumulation and variety of forms of withanolides. Researchers became interested in all the known withanolides variants because of their health-promoting activities [94-99].

Major Withanolides found in this species, such as withanolide A and withaferin A, have been shown to exhibit distinct anti-carcinogenic, anti-Parkinson's, and anti- Alzheimer's properties [100,101]. Gynecological diseases, bronchitis, arthritis, rheumatism, and drug addiction, such as opiate addiction, are also treated with Withania somnifera $[95,102]$. 
Field-grown plant materials have traditionally been utilized for commercial withanolides synthesis, although genotype and environmental circumstances have a significant impact on product quality and phytochemical constituent levels $[103,104]$. Field cultivation is time-consuming and labor-intensive, and it cannot supply the global demand for Ashwagandha. Transferring these roots to suspension culture and mass propagating them in bioreactors reduces the time gap between them and field-grown roots while also ensuring high quality [105].

Plant cell and organ cultures are potential methods for obtaining important metabolites specific to plants [51]. In vitro root culture of Withania somnifera has already been attempted in a few cases [106]. Within five weeks, adventitious roots cultivated in flasks with halfstrength MS liquid medium containing $0.5 \mathrm{mg} / \mathrm{L}$ IBA and $30 \mathrm{~g} / \mathrm{L}$ accumulated more biomass (108.48 g/L fresh weight and $10.76 \mathrm{~g} / \mathrm{L}$ dry weight) and had a higher withanolideA content (8.8 $0.20 \mathrm{mg} / \mathrm{g}$ dry weight). In suspension cultures, there was a nearly 11 fold increase in fresh biomass, and adventitious root biomass produced in suspension cultures had a 21-fold higher withanolide A content when compared to the leaves of wild plants [104]. After treating root biomass (11.70 g FW) with $150 \mu \mathrm{M}$ SA for a 4-h elicitor exposure period, $64.65 \mathrm{mg} / \mathrm{g}$ dry weight withanolide A (48-fold), $33.74 \mathrm{mg} / \mathrm{g}$ dry weight withanolide B (29-fold), $17.47 \mathrm{mg} / \mathrm{g}$ dry weight withaferin A (20-fold), $42.88 \mathrm{mg} / \mathrm{g}$ dry weight withanone (37-fold), $5.34 \mathrm{mg}-1$ dry weight 12-deoxy withastramonolide (ninefold), When compared to untreated cultures, $7.23 \mathrm{mg} / \mathrm{g}$ dry weight withanoside $\mathrm{V}$ (sevenfold) and $9.45 \mathrm{mg} / \mathrm{g}$ dry weight withanoside IV (ninefold) were obtained after 10 days of elicitation (40th day of culture) [107].

The influence of carbon source and initial medium $\mathrm{pH}$ on the growth and synthesis of withanolide A in Withania somnifera adventitious root cultures was examined. A $2 \%$ sucrose concentration was shown to be optimum for both biomass $(113.58 \mathrm{~g} / \mathrm{L} \mathrm{FW}$ and $11.33 \mathrm{~g} / \mathrm{L}$ dry weight) and secondary metabolite accumulation $(8.93 \mathrm{mg} / \mathrm{g}$ dry weight). The biomass of adventitious roots was best when the initial medium $\mathrm{pH}$ was $5.8(113.26 \mathrm{~g} / \mathrm{L} \mathrm{FW}$ and $11.33 \mathrm{~g} / \mathrm{L}$ dry weight), whereas withanolide A production was highest when the medium pH was 5.5 (9.09 mg/g dry weight) [108].

For secondary adventitious root proliferation, primary adventitious roots with an inoculum mass of $15 \mathrm{~g} \mathrm{FW}$ were cultivated for 6 weeks in the same medium. Aluminum chloride at $10 \mathrm{mg} / \mathrm{L}$ was used as an abiotic elicitor at the end of a 4-week culture with a 4-h exposure time, which increased withanolides productivity. When compared to aluminum chloride treatment under similar growth conditions, the biotic elicitor chitosan at $100 \mathrm{mg} / \mathrm{L}$ stimulated higher production of all withanolides [107].

In hairy root culture of Withania somnifera, [108] reported 3 percent sucrose to be optimum for biomass accumulation (11.92 $\mathrm{g} / \mathrm{L}$ dry weight) while 4 percent sucrose stimulated the formation of withanolide A $(13.28 \mathrm{mg} / \mathrm{g}$ dry weight). Hairy root biomass was maximum at pH 5.8 (12.1 g/L dry weight) and withanolide A production was highest at pH 6.0. Hairy root induction was used on transformed Withania Somnifera Ws-Sgtl4 leaf explants, and biomass accumulation was measured. Salicylic acid and methyl jasmonate were used to examine Ws-Sgtl4 gene expression at various time exposures.

The findings revealed that Ws Sgtl4 gene expression increased overall withanolide yield and withanolides-A synthesis in Withania somnifera hairy root culture in response to elicitors [109]. After 30 days of culture, hairy roots with an initial inoculum mass of $5 \mathrm{~g}$ FW were elicited separately with methyl jasmonate and salicylic acid (SA) at various concentrations for varying exposure durations. From 40 day-old harvested hairy roots elicited with $150 \mu \mathrm{M}$ SA for $4 \mathrm{~h}$ exposure time, increased production of biomass (32.68 $\mathrm{g} \mathrm{FW}$ and $5.54 \mathrm{~g}$ dry weight; 1.23-fold higher), withanolide A (132.44 mg/g dry weight; 58-fold higher), withanone ( $84.35 \mathrm{mg} / \mathrm{g}$ dry weight; 46 -fold higher), and withaferin A (70.72 mg/g dry weight; 42-fold higher) were obtained [110]. The hairy roots were elicited with natural polysaccharides of sodium alginate (SA), k-carrageenan $(\mathrm{kC})$, and chitosan $(\mathrm{CH})$ at varied concentrations, which resulted in a large amount of WA compound in majority of cases. Among the various elicitors, $100 \mathrm{mg} / \mathrm{LCH}$ resulted in a 4.03-fold increase in WA production 
as compared to the control. This is the first time that natural polysaccharides have been employed as elicitors in Withania somnifera hairy roots [111].

According to above mention study total withanolides contents in transgenic hairy roots of Withania somnifera were higher than the non-transformed roots. Moreover, treatment with elicitors such as SA and MeJA were discovered to increase the accumulation of withanolides in hairy roots, so it is preferred over adventitious root culture for large-scale production of secondary metabolites in Withania somnifera.

\subsection{Echinacea purpurea}

Echinacea purpurea, also known as purple coneflower, has been acknowledged globally owing to its increasing medicinal worth. The main bioactive compounds reported in Echinacea extracts are phenolics, alkylamides, and polysaccharide/glycoproteins. The phenolics majorly include Echinacoside, cynarin, cichoric acid, caftaric acid, and chlorogenic acids (CADs), Of these, cichoric acid is the center of attention as it displays immunostimulatory properties and is shown to promote phagocytosis both in vitro and in vivo. It has also been reported to possess antiviral activity prominently against HIV [112].

E. purpurea extracts have been reported to be effective against various viruses, respiratory tract infections, inflammatory disorders, and skin diseases like atopic eczema [113]. Furthermore, in vitro studies suggested that E. purpurea extracts possessed high antioxidant, antidiabetic, and antihypertensive properties [77]. Despite the enormous success of $E$. purpurea on the market, some major challenges pose problems to the industry such as seed dormancy, low germination rates a relatively long maturation time, and fungal pathogens with the substantial challenge being product standardization [19,112].

Conventionally, propagation of E. purpurea was done by seeds, crown division, or root cuttings but these processes have restricted propagation potential for producing sizeable numbers of plants, can cause genetic variability, and are time-consuming. In vitro micropropagation techniques, such as adventitious root, hairy root, and somatic embryogenesis, have the potential to produce hundreds of clonal plants from cuttings of a parent plant [21].

The viability of employing mass cultivation of the adventitious roots of E. purpurea in balloon-type bubble bioreactors was evaluated to produce caffeic acid derivatives, which are known for their pharmaceutical and therapeutic values. After 4 weeks of culture in BTBB (5 L capacity with $4 \mathrm{~L}$ half-strength MS media), an approximately 10-fold increase was reported in biomass and secondary compound. An inoculum density and aeration rate of $7 \mathrm{~g} / \mathrm{L}$ and $0.1 \mathrm{vvm}$, respectively, were reported to be best suitable for inducing the accumulation of biomass and secondary metabolites. The concentration of cichoric acid was the highest (26.64 mg/g dry weight) of the three caffeic acid derivatives evaluated [114].

The effects of 24-epibrassinolide (24-eBL) and 1-phenylalanine (1-phy) were evaluated on different parameters such as the root growth, total phenolics, total flavonoids, and caffeic acid derivatives (CADs) accumulation in Agrobacterium rhizogenes mediated hairy roots of Echinacea purpurea. $1.0 \mathrm{mg} / \mathrm{L} 24-\mathrm{eBL}$ was reported as the optimum concentration, among the 24-eBL applications, which provided the highest contents of total phenolics, total flavonoids, cichoric acid, caftaric acid, Echinacoside, and p-coumaric acid. The results displayed that 24-eBL and 1-phy treatments successfully enhanced the production of secondary metabolites in transgenic hairy roots of E. purpurea and 24-eBL implementations were considered as a more effective strategy when compared to l-phy [115].

Rhizobium-based transformation efficiency of Echinacea purpurea is influenced by several factors and therefore, there is room for optimization. For instance, the effectiveness of the utilized bacterial strain is important; R1000 strains were superior for transforming E. purpurea with petioles, whereas A4 strains gave the best results with leaf explants [116]. During co-cultivation of agrobacterium with the plant tissue, the addition of inducers to the medium also enhances efficacy. Ref. [87] reported that indole-3-butyric acid increased the production of hairy roots in E. purpurea by 14-folds. To improve transformation, other inducers of Rhizobium-associated gene transfer in plants such as 6-benzylaminopurine, 2,4dichloro phenoxyacetic acid have also been applied to E. purpurea hairy root cultures [116]. 
The use of elicitors such as plant hormones, biotic and abiotic compounds, and physical injury displays promising results in stimulating the production of valuable secondary metabolites [112].

Supplementation of sodium nitroprusside to the growth medium, in the adventitious root culture of E. Purpurea, increased the accumulation of flavonoids and CADs [117]. Salicylic acid displayed a twofold increase in cichoric and caftaric acid in flower heads of E. purpurea flower heads, and when applied as a foliar spray to field-grown plants, approximately a fourfold increase of CAD in the roots was reported [118]. Biotic elicitors such as yeast extract imitate a pathogenic fungal infection and consequently stimulate the production of phenolics in Echinacea purpurea [119].

Inspire of these imposing effects on phytochemical content, elicitors are also reported to have an inhibitory effect on growth. For this purpose, a two-phased approach is considered inevitable for the optimization of phytochemical production. Ref. [120] evaluated that addition of methyl jasmonate to the culture on the 28th day, had a 3-fold increase in the Echinacoside content in root cultures of E. angustifolia, without reducing the biomass. As the production of both biomass and phytochemicals often decreases at industrial scales, therefore it is better to utilize chemical elicitors in large-scale bioreactors [29].

The basis of tissue culture is growth medium and innumerable studies have evaluated what combination of nutrients provides the finest growing environment for Echinacea purpurea cultures. The optimal media may differ, and it mostly depends on the E. purpurea species and tissue being cultured. For example, [41] in earlier work, reported that the maximum biomass of adventitious roots of E. angustifolia was obtained on a half-strength Murashige Skoog (MS) medium. However, later on, they reported that the maximum biomass of adventitious roots, as well as maximum phenolic content of E. purpurea, could be obtained on one-quarter strength Murashige Skoog medium along with $50 \mathrm{~g} / \mathrm{L}$ sucrose and $1 \mathrm{mg} /$ L IBA [29].

Light treatment is currently reported to alter secondary metabolite formation. The effects of UV-B radiation on E. purpurea cultures for short periods in varying exposures were evaluated. All UV-B treatments enhanced caffeic acid and antioxidant activity of callus cells and growth parameters, total phenols content, and antioxidant activity of cell suspensions in a dose-dependent manner. Later on, the same group also tested both types of E. purpurea cultures by varying the doses of UV-C and reported similar results [121]. In recent times, ultrasound treatment has been developed as a method of enhancing plant secondary metabolite content, but it has not been considerably tested with E. purpurea. Two studies with E. purpurea hairy roots grown in bioreactors evaluated that between days 15 and 20 of culture, one 6-min ultrasound treatment at $40 \mathrm{kHz}$, remarkably enhanced both fresh weight and cichoric acid content over 30 days [21].

Hairy root cultures have several notable properties that are extremely useful for research and industry, which include accelerated growth rate, spontaneous regeneration of shoots, as well as chemical and morphological similarity to the roots of a wild-type plant [122]. Hairy root cultures of all three commercially important Echinacea purpurea species are reported to produce high levels of secondary metabolites, namely polysaccharides, alkylamides, CADs, and other phenolics $[19,20]$. Moreover, transformed roots of $E$. purpurea are genetically stable and possess the ability to maintain a constant production of valuable metabolites over a long period [21]. Furthermore, the rapid growth of E. purpurea hairy root cultures on hormone-free media makes them an outstanding means to generate biomass quickly. Due to these characteristics, hairy root cultures of E. purpurea are preferred over adventitious root cultures to produce valuable compounds.

\subsection{Ajuga bracteosa}

Ajuga bracteosa commonly referred to as Neel-kanthi is a medicinal herb of the family Lamiacea. Traditionally, it has been used as a favorable alternative to the wonder herb cinchona as anti-fungal, stimulant, tonic, and constringent [123]. Recent research has shown that $A$. bracteosa extracts have positive results in the treatment of inflammation, 
diabetes, malaria, palsy, stomach pain, intestinal dysfunctions, tuberculosis, hypertension, and cancer [124].

The prominent class of secondary metabolites found in different parts of A. bracteosa includes phenolic acids, flavonoids, essential oils, tannins, and anolides, etc. [125]. 20Hydroxyecdysone $(20 \mathrm{HE})$ is an ecdysterone that accumulates in A. bracteosa is regarded as a naturally occurring hormone that can control the ecdysis and metamorphosis of arthropods. Furthermore, positive effects of this bioactive compound against human carcinoma cell lines have also been reported [126].

It is getting endangered globally due to devastating harvesting by pharmaceutical industries in its different habitats. Therefore, there is a dire need to protect this medicinal herb by conservation and sustainable utilization. Adventitious root culture is a very appealing technology, among all the other cell culture technologies including hairy root cultures because it has the potential to produce bioactive metabolites in higher quantities, disregarding the environmental constraints in limited time and space [123]

Elicitation strategy is well known to enhance secondary metabolite production. Ref. [123] investigated the effects of two prominent elicitors, methyl jasmonate (MeJA) and phenylacetic acid (PAA) on growth parameters, secondary metabolites production, and antioxidant potential in adventitious root suspension cultures of $A$. bracteosa. The results showed a considerable increase in biomass accumulation, on day 40 of culture as well as the elicitors-induced enhancement in phenolic content, flavonoid content, and antioxidant activity in root suspension cultures of $A$. bracteosa.

Light regulates almost all plant developmental processes. Ref. [123] evaluated the effects of $\alpha$-naphthalene acetic acid (NAA) in adventitious root cultures of A. bracteos $a$ under different spectral lights on different parameters such as growth, secondary metabolism, and biosynthesis of phenolic acid. In AR cultures, grown in presence of blue light, maximum production of polyphenols and flavonoids was recorded. Whereas normal white light and blue light contributed to the highest total protein content of $(401.6 \mu \mathrm{g})$ and maximum superoxide dismutase (SOD; $2.5 \mathrm{nM}$ ) activity respectively. Furthermore, in comparison with other monochromatic lights, red light considerably enhanced the antioxidant potential of the AR cultures.

Ref. [127] for the very first time reported the biotechnologically enhanced production of phytoecdysteroids in A. bracteosa both via transformation and elicitation. pRi TR-DNA genes were reported to act as key players in the determination of the morphology of hairy roots. Typical transgenic hairy roots produced more phytoecdysteroids, on the other hand, those with callus-like morphology resulted in enhanced biomass. Elicitation treatment with MeJA for 14 days further increased phytoecdysteroids level.

Other most prominent medicinal plant species for which adventitious root and hairy root culture have been established to produce valuable compounds by employing bioreactors or elicitation strategies are enlisted in Tables 1 and 2. The increasing demand for natural drug raw materials particularly in the pharmaceutical industry can be fulfilled by these strategies. 
Table 1. List of adventitious root culture of medicinal plant species to produce valuable compounds by employing bioreactors or elicitation strategy.

\begin{tabular}{|c|c|c|c|c|c|c|c|c|}
\hline Plant & Explant Used & Valuable Compound & $\begin{array}{l}\text { Culture Conditions } \\
\text { and PGRs }\end{array}$ & Elicitation Strategy & $\begin{array}{l}\text { Increase in Yield of } \\
\text { Valuable Compound }\end{array}$ & Bioreactor Employed & $\begin{array}{c}\text { Optimization Strategy } \\
\text { of Culture Conditions } \\
\text { and Bioreactor }\end{array}$ & Reference \\
\hline $\begin{array}{c}\text { Ajuga bracteosa Wall. ex } \\
\text { Benth. }\end{array}$ & Leaf explants & $\begin{array}{l}\text { poly phenols } \\
\text { flavonoids }\end{array}$ & $\begin{array}{l}\text { MS media + } \\
\text { (1.5) NAA }\end{array}$ & $\begin{array}{l}\text { Different } \\
\text { Spectral lights }\end{array}$ & $\begin{array}{l}\text { Enhanced production } \\
\text { of polyphenols } \\
\text { (44.2 } \mathrm{mg}) \text { and } \\
\text { flavonoids }(2.51 \mathrm{mg}) \\
\text { were observed in } \\
\text { presence of blue light. }\end{array}$ & - & $\begin{array}{c}\text { pH 5.6-5.8 } \\
\text { photoperiod (16 h light } \\
\text { and } 8 \mathrm{~h} \text { dark) under } \\
\text { cool-white light } \\
\left(\sim 100 \mu \mathrm{mol} / \mathrm{m}^{2} / \mathrm{s}\right) \\
\text { Temperature } 25 \pm 2^{\circ} \mathrm{C}\end{array}$ & [123] \\
\hline Allamanda cathartica L. & Nodal segment & iridoids & $\begin{array}{c}\frac{1}{2} \mathrm{MS} \text { media }+ \\
0.1 \mu \mathrm{M} \text { IAA, } 0.5 \mu \mathrm{M} \\
\text { IBA, } \\
1.0 \mu \mathrm{M} \text { NAA }\end{array}$ & - & $\begin{array}{c}\text { Total yield of iridoid } \\
\text { glycoside content was } \\
\text { highest in S3 sample } \\
5.53 \pm 0.03 \% \text { treated } \\
\text { with } 0.5 \mathrm{M} \mathrm{IBA}+ \\
4 \text { percent sucrose+ } \\
120 \mathrm{mM} \mathrm{NaCl} .\end{array}$ & - & $\begin{array}{c}\text { Sucrose } 3 \% \\
\text { NACL } \\
\text { supplementation } \\
\text { Culture period: } \\
4 \text { weeks } \\
\text { pH } 5.8 \\
\text { relative humidity: } \\
55-60 \%\end{array}$ & [128] \\
\hline Angelica gigas N. & Seeds & $\begin{array}{c}\text { decursin \& } \\
\text { decursinol angelate }\end{array}$ & $\begin{array}{c}\text { MS media }+1.0 \mathrm{mg} / \mathrm{L} \\
\mathrm{IBA}+0.6 \mathrm{~g} / \mathrm{L} \text { caseine } \\
\text { hydrolysate }\end{array}$ & $\begin{array}{c}\text { yeast extract, chitin, } \\
\text { MeJA, } \\
\text { SA, and copper }\end{array}$ & $\begin{array}{l}1.5 \text {-fold increase in } \\
\text { plant yield. } \\
1.7 \text {-fold increase in } \\
\text { production of decursin. }\end{array}$ & - & $\begin{array}{c}\text { Sucrose: } 30 \mathrm{~g} / \mathrm{L} \\
\text { pH: } 5.7 \\
\text { Subculturing, every } \\
21 \text { days. } \\
\end{array}$ & [129] \\
\hline Artemisia amygdalina D. & Leaf explant & Essential oils & $\begin{array}{c}\text { MS media + } \\
1.0 \mathrm{mg} / \mathrm{L} \\
\alpha \text {-naphthalene acetic } \\
\text { acid (NAA) }\end{array}$ & methyl jasmonate & $\begin{array}{l}\text { (Me-J: } 0.5 \mathrm{mg} / \mathrm{L}) \\
\text { resulted in the higher } \\
\text { production of total } \\
\text { phenolic content } \\
(3.6 \mathrm{mg}) \text {, total flavonoid } \\
\text { content }(2.3 \mathrm{mg}) \text {, and } \\
\text { phenylalanine } \\
\text { ammonia-lyase } \\
(4.8 \mathrm{U} / \mathrm{g} \times \mathrm{FW}) .\end{array}$ & - & $\begin{array}{l}\text { light intensity: } \\
\sim 40 \mu \mathrm{M} / \mathrm{m}^{2} \mathrm{~s} \\
\text { Humidity: } 70 \% \\
\text { Sucrose: } 3 \%\end{array}$ & [130] \\
\hline $\begin{array}{l}\text { Artimisia scoparia } \\
\text { Waldst. and Kit. }\end{array}$ & Leaf explant & $\mathrm{DPPH}$ & $\begin{array}{c}\mathrm{MS} \text { media }+1.0 \mathrm{mg} / \mathrm{L} \\
\text { PAA and NAA }\end{array}$ & MeJA & $\begin{array}{c}87 \% \text { antioxidant } \\
\text { potential was achieved } \\
\text { in presence of } 0.5 \mathrm{mg} / \mathrm{L} \\
\text { MeJA. }\end{array}$ & - & $\begin{array}{l}\text { Relative humidity: } 70 \% \\
\text { light intensity of } \\
\sim 40 \mu \mathrm{M} / \mathrm{m}^{2} \mathrm{~s} \\
\text { sucrose: } 3 \% \\
\text { pHH } 5.8 \\
\text { Culture period: } 44 \text { days }\end{array}$ & [130] \\
\hline Asphodeloideae L. & Young shoots & $\begin{array}{l}\text { Aloe-emodin and } \\
\text { chrysophanol }\end{array}$ & $\begin{array}{l}\text { MS liquid media with } \\
0.3 \mathrm{mg} / \mathrm{L} \mathrm{IBA}\end{array}$ & $\begin{array}{l}\text { salicylic acid, methyl } \\
\text { jasmonate, and } \\
\text { ethephon }\end{array}$ & $\begin{array}{c}\text { Aloe-emodin increased } \\
\text { 10-11-fold by SA } \\
\text { treatment. } \\
\text { Chrysophanol was } \\
\text { increased by 5-13-folds } \\
\text { by SA treatment. }\end{array}$ & - & $\begin{array}{c}30 \mathrm{~g} / \mathrm{L} \text { sucrose } \\
\mathrm{pH} 5.8 \\
\text { constant light } \\
\text { conditions (light } \\
\text { intensity: } 7 \mathrm{mE} / \mathrm{m}^{2} \mathrm{~s} \text { ) } \\
\text { culture period: } 3 \text { weeks }\end{array}$ & [31] \\
\hline
\end{tabular}


Table 1. Cont.

\begin{tabular}{|c|c|c|c|c|c|c|c|c|}
\hline Plant & Explant Used & Valuable Compound & $\begin{array}{l}\text { Culture Conditions } \\
\text { and PGRs }\end{array}$ & Elicitation Strategy & $\begin{array}{l}\text { Increase in Yield of } \\
\text { Valuable Compound }\end{array}$ & Bioreactor Employed & $\begin{array}{c}\text { Optimization Strategy } \\
\text { of Culture Conditions } \\
\text { and Bioreactor }\end{array}$ & Reference \\
\hline $\begin{array}{c}\text { Astragalus } \\
\text { membranaceus } \mathrm{L} .\end{array}$ & Roots & $\begin{array}{l}\text { Calycosin-7-O- } \beta-\mathrm{d}- \\
\text { glucoside } \\
\text { (CG) }\end{array}$ & $\underset{\text { IBA }}{\text { MS media }+7 \mathrm{mg} / \mathrm{L}}$ & $\begin{array}{c}\text { MeJA } \\
\text { L-phenylalanine }\end{array}$ & $\begin{array}{l}\text { 2.02-fold increase in CG } \\
\text { content, with } 200 \mu \mathrm{M} \\
\text { MeJA for } 8 \text { days. } \\
\text { 3.12-fold increase in CG } \\
\text { by feeding } \\
\text { MeJA-elicited CG with } \\
\text { 1-phenylalanine. }\end{array}$ & - & $\begin{array}{l}\text { Sucrose: } 30 \mathrm{~g} / \mathrm{L} \\
\text { PEG treatment }\end{array}$ & [131] \\
\hline $\begin{array}{c}\text { Astragalus } \\
\text { membranaceus var. } \\
\text { mongholicus } \mathrm{F} \text {. }\end{array}$ & Shoot & $\begin{array}{l}\text { calycosin-7-O- } \beta \text {-D- } \\
\text { glucoside and } \\
\text { astragaloside IV }\end{array}$ & $\underset{\text { NAA }}{\text { MS media }+1 \mathrm{mg} / \mathrm{L}}$ & $\begin{array}{l}\text { Green leaf volatiles } \\
\text { (hexanal, hexanol, and } \\
\text { E-2-hexenal) }\end{array}$ & $\begin{array}{l}\text { Treatments with } \\
\text { hexanol and } \\
\text { E-2-hexenal } \\
\text { significantly increased } \\
\text { the content of } \\
\text { astragaloside IV by } \\
81.67 \% \text { and } 81.41 \% . \\
\text { Treatments with } \\
\text { hexanal and hexanol } \\
\text { increased the CG } \\
\text { content up to } 56.07 \% \\
(0.57 \pm 0.05 \mathrm{mg} / \mathrm{g}) \text { and } \\
65.18 \%(0.60 \pm \\
0.02 \mathrm{mg} / \mathrm{g}), \\
\text { respectively }\end{array}$ & - & $\begin{array}{l}\text { Sucrose: } 30 \mathrm{~g} / \mathrm{L} \\
\text { Photo period: } 16 \mathrm{~h} \\
\text { light } / 8 \mathrm{~h} \text { dark } \\
\text { Culture period: } \\
4 \text { weeks }\end{array}$ & [132] \\
\hline Celastrus paniculatus $\mathrm{W}$. & Leaf explants & Celastrol & $\begin{array}{l}\text { MS media }+0.3 \mathrm{mg} / \mathrm{L} \\
\text { IAA }\end{array}$ & $\begin{array}{l}\text { Silver nanoparticles } \\
\text { and acetosyringone }\end{array}$ & $\begin{array}{l}\text { Celastrol increased } \\
1.87 \text {-fold by treatment } \\
\text { with } 10 \mu \mathrm{g} / \mathrm{mL} \text { of } \\
\text { AgNPs }(48 \mathrm{~h} \text { exposure). }\end{array}$ & - & $\begin{array}{l}\text { 3\% sucrose pH } 5.8 \\
\text { Culture period: } \\
2 \text { weeks }\end{array}$ & [133] \\
\hline Clitoria teretea $\mathrm{L}$. & Seeds & $\begin{array}{c}\text { pentacyclic } \\
\text { triterpenoid, saponins, } \\
\text { flavonoids, } \\
\text { anthocyanins }\end{array}$ & $\begin{array}{c}\frac{1}{2} \mathrm{MS} \text { media }+ \\
2.50 \mathrm{mg} / \mathrm{L} \mathrm{NAA}, \\
2.50 \mathrm{mg} / \mathrm{L} \\
\text { (4-chloroindole-3-acetic } \\
\text { acid) } \\
\text { 4-Cl-IAA }\end{array}$ & - & $\begin{array}{l}\text { Taraxasterol content } \\
\text { was detected with peak } \\
\text { area } 72.01 \% \text { and } 6.35 \% \\
\text { respectively. }\end{array}$ & - & $\begin{array}{c}\text { Sucrose: } 3 \% \\
\text { Photoperiod: } 16 / 8 \mathrm{~h} \\
\text { Light intensity: } \\
32.5 \mu \mathrm{E} / \mathrm{m}^{2} \mathrm{~s} \\
\text { Culture period: } \\
6 \text { weeks }\end{array}$ & [134] \\
\hline $\begin{array}{c}\text { Codonopsis lanceolata } \\
\text { S.Z. }\end{array}$ & Leaf explant & $\begin{array}{l}\text { flavonoids, total } \\
\text { phenolic compound, } \\
\text { and DPPH. }\end{array}$ & $\begin{array}{l}\text { MS media }+1.0 \mathrm{mg} / \mathrm{L} \\
\text { IBA }\end{array}$ & MeJA and SA & $\begin{array}{l}\text { By treatment with } 20 \\
\mu \mathrm{M} \text { MeJA, DPPH } \\
\text { scavenging activity was } \\
24.2 . \\
\text { Flavonoids: } 38.45 \\
\text { mg/g of C. lanceolata } \\
\text { Phenolic content: } \\
74.53 \mathrm{mg} / \mathrm{g}\end{array}$ & - & $\begin{array}{l}\text { Culture period: } \\
5 \text { weeks } \\
\text { Sucrose: } 30 \mathrm{~g} / \mathrm{L}\end{array}$ & [135] \\
\hline
\end{tabular}


Table 1. Cont.

\begin{tabular}{|c|c|c|c|c|c|c|c|c|}
\hline Plant & Explant Used & Valuable Compound & $\begin{array}{l}\text { Culture Conditions } \\
\text { and PGRs }\end{array}$ & Elicitation Strategy & $\begin{array}{l}\text { Increase in Yield of } \\
\text { Valuable Compound }\end{array}$ & Bioreactor Employed & $\begin{array}{c}\text { Optimization Strategy } \\
\text { of Culture Conditions } \\
\text { and Bioreactor }\end{array}$ & Reference \\
\hline Curculigo orchioides G. & Leaf explants & $\begin{array}{l}\text { Phenolics and } \\
\text { Curculigoside }\end{array}$ & $\begin{array}{l}\text { MS media }+3.0 \mathrm{mg} / \mathrm{L} \\
\text { NAA in liquid culture }\end{array}$ & - & $\begin{array}{c}\text { Adventitious roots } \\
\text { grown in modified } \frac{3}{4} \\
\text { strength of MS medium } \\
\text { showed the highest } \\
\text { amount of } \\
\text { curculigoside } \\
\text { (76.521 } \mu \mathrm{g} / \text { Treatment). }\end{array}$ & - & $\begin{array}{l}\frac{3}{4} \text { strength of MS } \\
\text { medium } \\
4 \%(w / v) \text { of sucrose }\end{array}$ & [136] \\
\hline $\begin{array}{l}\text { Decalepis salicifolia } \\
\text { (Bedd. ex Hook.f.) }\end{array}$ & Leaf & $\begin{array}{c}\text { Vanillin isomer: } \\
\text { 2-hydroxy-4- } \\
\text { methoxybenzaldehyde } \\
\text { (2H4MB), }\end{array}$ & $\begin{array}{c}\text { WPM liquid media + } \\
0.5 \mathrm{mg} / \mathrm{L} \text { NAA, } \\
1.0 \mathrm{mg} / \mathrm{L} \\
\text { Kinetin, } 0.3 \mathrm{mg} / \mathrm{L} \text { IBA }\end{array}$ & - & $\begin{array}{l}\text { The total production of } \\
\text { 2H4MB was 4.9-fold } \\
\text { higher in adventitious } \\
\text { root culture }(139.54 \mu \mathrm{g}) \\
\text { as compared to } \\
\text { field-grown plants } \\
\text { (28.62 } \mu \mathrm{g}) .\end{array}$ & - & $\begin{array}{c}\text { Sucrose: } 5 \% \\
\text { pH: } 7.0 \\
\text { culture period: } 60 \text { days }\end{array}$ & [128] \\
\hline Echinacea purpurea L. & roots & $\begin{array}{l}\text { caffeic acid derivatives } \\
\text { caftaric acid, } \\
\text { chlorogenic acid, and } \\
\text { cichoric acid. }\end{array}$ & $\underset{\text { IBA }}{\text { MS media }+2 \text { mg/L }}$ & - & $\begin{array}{c}\text { A } 10 \text {-fold increase in } \\
\text { biomass and secondary } \\
\text { compounds. } \\
\text { the concentration of } \\
\text { cichoric acid was the } \\
\text { highest ( } 26.64 \mathrm{mg} / \mathrm{g} \\
\text { dry weight) }\end{array}$ & $\begin{array}{c}\text { Balloon-type bubble } \\
\text { bioreactor. }\end{array}$ & $\begin{array}{c}\text { Sucrose: } 5 \% \\
\text { inoculum density: } \\
7 \mathrm{~g} / \mathrm{L} \mathrm{FW} \\
\text { aeration rate: } 0.1 \mathrm{vvm}\end{array}$ & [114] \\
\hline $\begin{array}{l}\text { Eleutherococcus } \\
\text { koreanum M. }\end{array}$ & Seed-derived plants & $\begin{array}{l}\text { eleutherosides B\&E, } \\
\text { chlorogenic acid, total } \\
\text { phenolics, and } \\
\text { flavonoids }\end{array}$ & $\begin{array}{c}\text { MS media }+5 \mathrm{mg} / \mathrm{L} \\
0.01 \mathrm{mg} / \mathrm{L} \text { TDZ }\end{array}$ & MeJA and SA & $\begin{array}{l}\text { At } 303.93 \mathrm{mg} / \mathrm{L} \text { of } \\
\text { MeJA production of } \\
\text { targeted bioactive } \\
\text { compounds was } \\
37.77 \% \text {. High } \\
\text { concentrations of MeJA } \\
\text { and SA increased } \\
\text { DPPH activity and } \\
\mathrm{H}_{2} \mathrm{O}_{2} \text { content in the } \\
\text { roots. }\end{array}$ & $\begin{array}{l}\text { Airlift bio- } \\
\text { reactors }\end{array}$ & $\begin{array}{c}\text { (HN4: NO3-, 5: 25) } \\
\text { Sucrose: } 30 \mathrm{~g} / \mathrm{L} \\
\text { Gelrite: } 2.3 \mathrm{~g} / \mathrm{L} \\
\text { density of } \mathrm{AR}=5 \mathrm{~g} / \mathrm{L} \\
\text { aeration volume }= \\
0.1 \mathrm{vvm}\end{array}$ & [84] \\
\hline
\end{tabular}


Table 1. Cont.

\begin{tabular}{|c|c|c|c|c|c|c|c|c|}
\hline Plant & Explant Used & Valuable Compound & $\begin{array}{l}\text { Culture Conditions } \\
\text { and PGRs }\end{array}$ & Elicitation Strategy & $\begin{array}{l}\text { Increase in Yield of } \\
\text { Valuable Compound }\end{array}$ & Bioreactor Employed & $\begin{array}{c}\text { Optimization Strategy } \\
\text { of Culture Conditions } \\
\text { and Bioreactor }\end{array}$ & Reference \\
\hline Eurycoma longifolia J. & Leaf & $\begin{array}{l}\text { Eurycomanone and } \\
\text { polysaccharides }\end{array}$ & $\begin{array}{c}\frac{3}{4} \mathrm{MS} \text { media }+3 \mathrm{mg} / \mathrm{L} \\
\text { IBA }\end{array}$ & - & $\begin{array}{l}8.8 \mathrm{mg} / \text { Leurycomanone } \\
\text { and } 2.4 \mathrm{~g} / \mathrm{L} \\
\text { polysaccharides } \\
\text { obtained after } 40 \text { days } \\
\text { of culture in Bubble } \\
\text { column bioreactor }\end{array}$ & $\begin{array}{l}\text { Bubble column } \\
\text { bioreactor }\end{array}$ & $\begin{array}{c}\text { Sucrose: } 40 \mathrm{~g} / \mathrm{L} \\
\text { inoculation density: } \\
5 \mathrm{~g} / \mathrm{L} \\
\text { Aeration rate: } 0.05 \mathrm{vvm} \\
\text { Culture period: } 40 \text { days }\end{array}$ & [138] \\
\hline Fagonia indica $\mathrm{L}$. & callus explants & $\begin{array}{l}\text { Gallic acid } \\
\text { Rutin } \\
\text { Myricetin } \\
\text { Catechin } \\
\text { Caffeic acid } \\
\text { Apigenin }\end{array}$ & $\begin{array}{c}\text { MS media }+(0.5,1.0 \text { or } \\
2.0 \mathrm{mg} / \mathrm{L}) \text { IBA, IAA or } \\
\text { NAA }\end{array}$ & $\begin{array}{l}\text { MeJA } \\
\text { PAA }\end{array}$ & $\begin{array}{c}\text { By } 0.5 \mathrm{mg} / \mathrm{L} \text { MeJA } \\
\text { treatment, maximum } \\
\text { Total Phenolic Content } \\
\text { (TPC; } 6.0 \mathrm{mg} \text { GAE/g of } \\
\text { dry weight) and Total } \\
\text { Flavonoid Content } \\
\text { (TFC; } 5.0 \mathrm{mg} Q \mathrm{QE} / \mathrm{g} \text { of } \\
\text { dry weight) were } \\
\text { achieved. } \\
\text { Gallic acid (148.0 } \pm \\
4.8 \mu \mathrm{g} / \mathrm{mg} \text { of dry } \\
\text { weight) } \\
\text { Rutin }(122.3 \pm 3.8 \\
\mu \mathrm{g} / \mathrm{mg} \text { of dry weight) } \\
\text { Apigenin }(25.3 \pm 0.6 \\
\mu \mathrm{g} / \mathrm{mg} \text { of dry weight), } \\
\text { Caffeic acid ( } 25.3 \pm \\
0.6 \mu \mathrm{g} / \mathrm{mg} \text { of dry } \\
\text { weight) and Catechin } \\
\text { (9.4 } \pm 0.07 \mu \mathrm{g} / \mathrm{mg} \text { dry } \\
\text { weight). }\end{array}$ & - & $\begin{array}{c}\text { Sucrose: } 3 \% \\
\text { MS salts: } 0.44 \% \\
\text { Culture period: } 33 \text { days } \\
\text { relative humidity: } 70 \% \\
\text { irradiance: } \\
35-45 \mu \mathrm{mol} / \mathrm{m}^{2} \mathrm{~s} \\
\text { pH: } 5.6-5.8\end{array}$ & [139] \\
\hline Gentiana scabra B. & Leaf & secoiridoids & $\begin{array}{l}\text { MS media }+3.0 \mathrm{mg} / \mathrm{L} \\
\text { NAA and } 0.25 \mathrm{mg} / \mathrm{L} \\
\text { TDZ }\end{array}$ & - & $\begin{array}{c}\text { HPLC revealed } \\
\text { Maximal } \\
\text { gentiopicroside ( } 25.59 \\
\pm 0.65 \mathrm{mg} / \mathrm{g} \text { dry } \\
\text { weight), swertiamarin } \\
(1.61 \pm 0.04 \mathrm{mg} / \mathrm{g} \text { dry } \\
\text { weight) and sweroside } \\
(4.42 \pm 0.11 \mathrm{mg} / \mathrm{g} \text { dry } \\
\text { weight) levels after } \\
4 \text { weeks culture }\end{array}$ & - & $\begin{array}{c}\text { Phytohormones: } \\
30 \mathrm{mg} / \mathrm{L} \\
\alpha \text {-naphthalene acetic } \\
\text { acid and } 0.25 \mathrm{mg} / \mathrm{L} \\
\text { thidiazuron. } \\
\text { Photoperiod: } 16 / 8-\mathrm{h} \\
\text { Culture period: } \\
8 \text { weeks }\end{array}$ & [140] \\
\hline
\end{tabular}


Table 1. Cont.

\begin{tabular}{|c|c|c|c|c|c|c|c|c|}
\hline Plant & Explant Used & Valuable Compound & $\begin{array}{l}\text { Culture Conditions } \\
\text { and PGRs }\end{array}$ & Elicitation Strategy & $\begin{array}{l}\text { Increase in Yield of } \\
\text { Valuable Compound }\end{array}$ & Bioreactor Employed & $\begin{array}{l}\text { Optimization Strategy } \\
\text { of Culture Conditions } \\
\text { and Bioreactor }\end{array}$ & Reference \\
\hline $\begin{array}{l}\text { Ginseng C.A.Mey. and } \\
\text { Echinacea L. }\end{array}$ & roots & $\begin{array}{c}\text { ginsenosides and } \\
\text { caffeic acid derivatives }\end{array}$ & MS media $+25 \mu \mathrm{M} \mathrm{IBA}$ & MeJA & $\begin{array}{l}\text { Higher production of } \\
\text { ginsenosides and } \\
\text { caffeic acid derivates } \\
\text { was achieved by the } \\
\text { establishment of } \\
\text { co-cultures with higher } \\
\text { inoculum proportion of } \\
\text { ginseng to Echinacea, } \\
\text { ensued by elicitation } \\
200 \mu \mathrm{M} \text { MeJA. }\end{array}$ & Air-Lift bioreactors & $\begin{array}{l}\text { Co-culture system } \\
\text { Inoculum proportion of } \\
\text { Ginseng to Echinacea } \\
\text { (4:1 and } 3: 2) \\
\text { Sucrose: } 50 \mathrm{~g} / \mathrm{L}\end{array}$ & [83] \\
\hline $\begin{array}{l}\text { Glycyrrhiza uralensis } \\
\text { DC. }\end{array}$ & root & $\begin{array}{c}\text { Flavonoids } \\
\text { glycyrrhizic acid } \\
\text { glycyrrhetinic acid } \\
\text { polysaccharide }\end{array}$ & $\underset{\text { IBA }}{\text { MS media }+1 \mathrm{mg} / \mathrm{L}}$ & $\begin{array}{l}10 \mathrm{kDa} \text { protein } \\
\text { fragments }\end{array}$ & $\begin{array}{c}10 \mathrm{kDa} \text { protein } \\
\text { fragments increased the } \\
\text { Flavonoids, } \\
\text { glycyrrhizic acid, } \\
\text { glycyrrhetinic acid, and } \\
\text { polysacharide by up to } \\
2.27 \text {-fold, } 2.64 \text {-fold, } \\
2.70 \text {-fold, and } 2.32 \text {-fold, } \\
\text { respectively as } \\
\text { compared to control } \\
\text { roots. }\end{array}$ & - & $\begin{array}{l}\text { Sucrose: } 30 \mathrm{~g} / \mathrm{L} \\
\text { Culture period: } 35 \text { days }\end{array}$ & [141] \\
\hline Gynura procumbens L. & Leaf explant & flavonoid & $\underset{\text { IBA }}{\text { MS media }+5 \mathrm{mg} / \mathrm{L}}$ & - & $\begin{array}{c}\text { Biomass yield of } \\
\text { adventitious roots of G. } \\
\text { procumbens in } \\
\text { temporary immersion } \\
\text { bioreactor increased by } \\
5 \text { folds. } \\
\text { Isoflavon was detected } \\
\text { in adventitious roots at } \\
\text { low sucrose treatment. } \\
\text { volatile compound and } \\
\text { adipic acid were found } \\
\text { in all treatments. }\end{array}$ & $\begin{array}{c}\text { Temporary Immersion } \\
\text { Bioreactors }\end{array}$ & $\begin{array}{l}\text { various concentrations } \\
\text { of sucrose }(1,3 \text {, and } 5 \%) \\
\text { various immersion } \\
\text { frequency }(15 \text { min each } \\
12 \mathrm{~h} ; 5 \text { min each } 3 \mathrm{~h}) . \\
\text { Culture period: } 21 \text { days }\end{array}$ & [142] \\
\hline Gynura procumbens L. & $\begin{array}{l}\text { Young leaves and } \\
\text { internodes }\end{array}$ & $\begin{array}{l}\text { Phenolic compounds } \\
\text { and flavonoids }\end{array}$ & $\begin{array}{l}\text { MS media }+5 \mathrm{mg} / \mathrm{L} \\
\text { IBA }\end{array}$ & - & $\begin{array}{c}\text { The greater yield of } \\
\text { Biomass } \\
(75.38 \pm 0.95 \mathrm{~g} / \mathrm{L}), \\
\text { Total phenolic } \\
\text { production } \\
\text { (27.98 mg/dry weight), } \\
\text { and } \\
\text { Flavonoid production } \\
\text { rates (256.24 mg/dry } \\
\text { weight) were achieved } \\
\text { from adventitious roots } \\
\text { culture in the BTBB. }\end{array}$ & $\begin{array}{l}\text { Balloon-Type Bubble } \\
\text { Bioreactor (BTBB). }\end{array}$ & $\begin{array}{c}\text { aeration rate: } \\
0.15 \mathrm{vvm} \text {. inoculum } \\
\text { density } 3 \mathrm{~g} / \mathrm{L} \\
\text { Sucrose: } 30 \mathrm{~g} / \mathrm{L} \\
\text { Culture period: } \\
28 \text { days. }\end{array}$ & [143] \\
\hline
\end{tabular}


Table 1. Cont.

\begin{tabular}{|c|c|c|c|c|c|c|c|c|}
\hline Plant & Explant Used & Valuable Compound & $\begin{array}{l}\text { Culture Conditions } \\
\text { and PGRs }\end{array}$ & Elicitation Strategy & $\begin{array}{l}\text { Increase in Yield of } \\
\text { Valuable Compound }\end{array}$ & Bioreactor Employed & $\begin{array}{c}\text { Optimization Strategy } \\
\text { of Culture Conditions } \\
\text { and Bioreactor }\end{array}$ & Reference \\
\hline $\begin{array}{l}\text { Hybanthus enneaspermus } \\
\text { L. }\end{array}$ & Leaf & L-Dopa & $\begin{array}{l}\text { MS media }+0.5 \mathrm{mg} / \mathrm{L} \\
\text { Indole-3-butyric acid } \\
\text { (IBA) }\end{array}$ & $\begin{array}{l}\text { SA, Yeast extract, MeJA, } \\
\text { AgNO3 }\end{array}$ & $\begin{array}{l}\text { Among the different } \\
\text { elicitors tested, } \\
\text { exposure to SA at } 100 \\
\mu \mathrm{M} \text { dosage for } 6 \mathrm{~h} \\
\text { enhanced L-dopa yield } \\
12.64 \mathrm{mg} / \mathrm{g} \text { dry weight } \\
\text { (dry weight) when } \\
\text { compared to control } \\
\text { culture }\end{array}$ & - & $\begin{array}{c}\text { sucrose: } 3 \% \\
\text { pH: } 5.8 \\
\text { exposure times }(2-8 \mathrm{~h}) \\
\text { elicitation period: } 6 \mathrm{~h} \\
\text { culture period: } 30 \text { days }\end{array}$ & [144] \\
\hline $\begin{array}{l}\text { Morinda coreia } \\
\text { Buch.-Ham. }\end{array}$ & Leaf & $\begin{array}{l}\text { Anthraquinones and } \\
\text { phenolic compounds }\end{array}$ & $\begin{array}{c}\frac{1}{2} \mathrm{MS} \text { media }+1.0 \mathrm{mg} / \mathrm{L} \\
\text { of Indole-3 butyric acid } \\
\text { (IBA) }\end{array}$ & chitosan & $\begin{array}{l}\text { On treatment with } 0.4 \\
\mathrm{mg} / \mathrm{mL} \text { chitosan } \\
\text { amount of } \\
\text { anthraquinones } \\
\text { (292.038 mg/g dry } \\
\text { weight) and phenolics } \\
\text { ( } 86.8 \mathrm{mg} / \mathrm{g} \text { dry weight) } \\
\text { increased till } 4 \text { th day of } \\
\text { the elicitation }\end{array}$ & - & $\begin{array}{c}\text { Two-phase and } \\
\text { two-stage culture } \\
\text { system } \\
\frac{1}{2} \text { MS media } \\
\text { Sucrose: }(1.5 \%) \text {. } \\
\text { chitosan }(0.2,0.4 \text { and } \\
0.8 \mathrm{mg} / \mathrm{mL}) \text {, growth } \\
\text { ratio } \\
\text { (5.082), fresh weight } \\
\text { (1.568 g) and dry } \\
\text { weight }(0.163 \mathrm{~g}) \text { of AR } \\
\text { were recorded } \\
\text { maximum with the } \\
\text { concentration } \\
\text { of } 1.0 \mathrm{mg} / \mathrm{L} \text { IBA. }\end{array}$ & [146] \\
\hline Oldenlandia umbellate $\mathrm{L}$. & shoots & Anthraquinones (AQ) & $\begin{array}{c}\text { MS media+ } 7.5 \mu \mathrm{M} \text { IBA } \\
1 \mu \mathrm{M} \text { IAA }\end{array}$ & $\begin{array}{c}\text { yeast extract, pectin, } \\
\text { xylan, } \\
\alpha \text {-keto glutaric acid } \\
\text { and L- phenylalanine } \\
\text { and piroxicam }\end{array}$ & $\begin{array}{l}\text { Treatment with } \\
50 \mathrm{mg} / \mathrm{L} \text { pectin, } \\
\text { resulted in } 2.19 \text {-fold } \\
\text { increase in AQ } \\
\text { production. }\end{array}$ & - & $\begin{array}{l}\text { Culture period: } 60 \text { days } \\
\text { Sucrose: } 3 \% \\
\text { pH: } 5.8\end{array}$ & [147] \\
\hline
\end{tabular}


Table 1. Cont.

\begin{tabular}{|c|c|c|c|c|c|c|c|c|}
\hline Plant & Explant Used & Valuable Compound & $\begin{array}{l}\text { Culture Conditions } \\
\text { and PGRs }\end{array}$ & Elicitation Strategy & $\begin{array}{l}\text { Increase in Yield of } \\
\text { Valuable Compound }\end{array}$ & Bioreactor Employed & $\begin{array}{c}\text { Optimization Strategy } \\
\text { of Culture Conditions } \\
\text { and Bioreactor }\end{array}$ & Reference \\
\hline Oplopanax elatus N. & Seeds & $\begin{array}{l}\text { flavonoids and } \\
\text { anthraquinone }\end{array}$ & $\underset{\text { IBA }}{\text { MS Media+ } 5 \text { mg/L }}$ & MeJA & $\begin{array}{l}\text { At } 200 \mu \mathrm{M}, \mathrm{MeJA} \\
\text { significantly increased } \\
\text { the contents of } \\
\text { quercetin, aloe-emodin, } \\
\text { rhein, and emodin, } \\
\text { while } 225 \mu \mathrm{M} \text { was the } \\
\text { optimal concentration } \\
\text { for kaempferide } \\
\text { accumulation. }\end{array}$ & $\begin{array}{l}\text { Air-lift balloon type } \\
\text { bioreactor }\end{array}$ & $\begin{array}{c}\text { Sucrose: } 30 \mathrm{~g} / \mathrm{L} \\
\text { pH: } 5.8 \\
\text { Culture period: } 30 \text { days }\end{array}$ & {$[148,149]$} \\
\hline Panax quinquefolius L. & Root & Ginsenosides & $\begin{array}{l}\text { MS media + } 1 \mathrm{mg} / \mathrm{L} 2 \\
4-\mathrm{D}, 0.25 \mathrm{mg} / \mathrm{L} \text { kinetin }\end{array}$ & $\begin{array}{l}\text { Pathogenic fungal } \\
\text { elicitors }\end{array}$ & $\begin{array}{l}\text { The maximum } \\
\text { ginsenoside production } \\
(276.0 \mathrm{mg} / \mathrm{L}) \text { was } \\
\text { achieved with the A. } \\
\text { panax }(4 \mathrm{mg} / \mathrm{L}) \text { extract. }\end{array}$ & $\begin{array}{l}\text { Balloon-type airlift } \\
\text { bioreactor }\end{array}$ & $\begin{array}{c}\text { sucrose: } 50 \mathrm{~g} / \mathrm{L} \\
\text { pH: } 5.8 \\
\frac{3}{4} \mathrm{MS} \text { medium } \\
\text { supplemented with } \\
5 \mathrm{mg} / \mathrm{L} \mathrm{IBA} \\
\text { air volume: } \\
100 \mathrm{~mL} / \mathrm{min} \\
\text { Culture period: } 30 \text { days } \\
\text { Elicitation period: } \\
8 \text { days }\end{array}$ & [90] \\
\hline $\begin{array}{l}\text { Panax vietnamensis Ha } \\
\text { et Grushv. }\end{array}$ & Leaf & saponins & $\begin{array}{c}\text { Modified MS Media }+5 \\
\text { and } 7 \mathrm{mg} / \mathrm{L} \text { IBA }+0.5 \text { or } \\
1 \mathrm{mg} / \mathrm{L} \text { of single BA, } \\
\text { Kin and TDZ }\end{array}$ & $\begin{array}{l}\text { JA, SA, YA and } \\
\text { Chitosan (CHN) }\end{array}$ & $\begin{array}{c}\text { Saponins maximum } \\
\text { productivity was } \\
\text { observed in } 150 \mathrm{mg} / \mathrm{L} \\
\text { YE. }\end{array}$ & Bubble bioreactor & $\begin{array}{c}\text { Sucrose: } 30 \mathrm{~g} / \mathrm{L} \\
\text { Ratio of } \mathrm{NH}_{4}^{+} \mathrm{NO}_{3} 7.19: \\
18.50 \mathrm{mM} / \mathrm{mM} \\
\mathrm{pH}: 5.8 \\
\text { culture period of } \\
56 \text { days }\end{array}$ & [151] \\
\hline $\begin{array}{c}\text { Perouskia abrotanoides } \\
\text { Karel. }\end{array}$ & Young leaves & $\begin{array}{l}\text { Cryptotanshinone } \\
\text { tanshinone IIA }\end{array}$ & $\begin{array}{l}\text { MS media }+2 \mathrm{mg} / \mathrm{L} \\
\text { (NAA) }\end{array}$ & $\begin{array}{c}\text { yeast extract (YE), } \\
(\mathrm{MeJA}), \mathrm{AgNO}_{3} \text {, and } \\
\text { sorbitol }\end{array}$ & $\begin{array}{c}\text { Increased } \\
\text { cryptotanshinone and } \\
\text { tanshinone IIA } \\
\text { production was } \\
\text { achieved with } \\
200 \mathrm{mg} / \mathrm{L} \mathrm{YE} \mathrm{and} 2525 \mathrm{MgNO} 3\end{array}$ & - & $\begin{array}{c}3 \% \text { sucrose } \\
\text { pH } 5.8 \pm 0.1 \\
\text { Culture period: } \\
3 \text { weeks (dark) }\end{array}$ & [152] \\
\hline
\end{tabular}


Table 1. Cont.

\begin{tabular}{|c|c|c|c|c|c|c|c|c|}
\hline Plant & Explant Used & Valuable Compound & $\begin{array}{l}\text { Culture Conditions } \\
\text { and PGRs }\end{array}$ & Elicitation Strategy & $\begin{array}{l}\text { Increase in Yield of Valuable } \\
\text { Compound }\end{array}$ & Bioreactor Employed & $\begin{array}{c}\text { Optimization Strategy } \\
\text { of Culture Conditions } \\
\text { and Bioreactor }\end{array}$ & Reference \\
\hline Plumbago indica $\mathrm{L}$. & Young leaf & plumbagin & $\begin{array}{c}\text { Gamborg's B5 liquid } \\
\text { media + +0.1 mg/L } \\
\text { NAA }\end{array}$ & $\begin{array}{c}\text { Chitosan }+ \\
\text { Diaion }{ }^{\circledR} \text { HP-20 addition }\end{array}$ & $\begin{array}{l}\text { Plumagin increased upto } \\
\text { 6.6-fold by chitosan treatment } \\
\text { for } 72 \mathrm{~h} \text {. The sequential } \\
\text { addition of Diaion }{ }^{\oplus} \mathrm{H} P-20(10 \\
\mathrm{g} / \mathrm{L}) \text { to the root cultures after } \\
\text { the chitosan treatment for } 48 \mathrm{~h} \\
\text { increased the plumbagin } \\
\text { production up to } 19.93 \\
\mathrm{mg} / \text { gdry weight, which was } \\
\text { 1.2- and } 10 \text {-fold higher than } \\
\text { the chitosan treated and } \\
\text { untreated root cultures } \\
\text { respectively. }\end{array}$ & - & $\begin{array}{c}\text { Sucrose: } 20 \mathrm{~g} / \mathrm{L} \\
\text { chitosan concentration: } \\
150 \mathrm{mg} / \mathrm{L} \\
\text { optimal contact period: } \\
72 \mathrm{~h} \\
\text { Culture period: } 20 \text { days }\end{array}$ & [153] \\
\hline Plumbago rosea $\mathrm{L}$. & Leaf explants & Plumbagin & $\begin{array}{l}\mathrm{MS} \text { media }+1.5 \mathrm{mg} / \mathrm{L} \\
\mathrm{IAA}+1 \mathrm{mg} / \mathrm{L} \mathrm{IBA}\end{array}$ & $\begin{array}{c}\text { Jasmonic acid } \\
\text { yeast extract and } \\
\text { sodium salicylate }\end{array}$ & $\begin{array}{l}50 \mu \mathrm{M} \text { jasmonic acid for three } \\
\text { days increased plumbagin } \\
\text { content in roots to } 1.23 \% \text { dry } \\
\text { weight. }\end{array}$ & - & $\begin{array}{l}\text { 3/4th strength MS } \\
\text { liquid media } \\
\text { Sucrose: } 30 \% \\
\text { Root inoculum: } 2 \mathrm{~g} / \mathrm{L}\end{array}$ & [154] \\
\hline $\begin{array}{l}\text { Polygonum } \\
\text { Multiflorum Thunb. }\end{array}$ & Leaf & $\begin{array}{l}\text { Phenolics and } \\
\text { flavonoids }\end{array}$ & $\begin{array}{l}\text { Full-strength MS media } \\
\quad+2 \mathrm{mg} / \mathrm{L}\end{array}$ & $\begin{array}{l}\text { Methyl jasmonate } \\
\text { (MeJA) and salicylic } \\
\text { acid (SA) }\end{array}$ & $\begin{array}{l}\text { Total phenolic compounds } \\
\text { increased by } 53.08 \mathrm{mg} \cdot \mathrm{g}^{-1} \text { dry } \\
\text { weight and total flavonoids } \\
\text { increased by } 25.10 \mathrm{mg} / \mathrm{g} \text { dry } \\
\text { weight }\end{array}$ & Air lift bioreactor & $\begin{array}{c}\text { sucrose: } 5 \% \\
\text { Culture period: } \\
4 \text { weeks } \\
\text { Aeration rate: } 0.1 \mathrm{vvm} \\
\text { (air volume flow per } \\
\text { unit of culture volume } \\
\text { per minute) }\end{array}$ & [87] \\
\hline Prunella vulgaris $\mathrm{L}$. & Leaf & $\begin{array}{l}\text { Phenolics and } \\
\text { flavonoids }\end{array}$ & $\mathrm{MS}+0.5 \mathrm{mg} / \mathrm{L} \mathrm{NAA}$ & - & $\begin{array}{l}\text { Higher TPC ( } 0.995 \mathrm{GAE} \\
\mathrm{mg} / \mathrm{g} \text {-DRB) and TFC (6.615 } \\
\text { RE mg/g- DRB) were } \\
\text { observed in } 0.5 \mathrm{mg} / \mathrm{L} \text { NAA } \\
\text { treated cultures. }\end{array}$ & - & $\begin{array}{c}\text { sucrose: } 30 \mathrm{~g} / \mathrm{L} \\
\text { Photoperiod: } 16 / 8 \mathrm{~h} \\
\text { Light intensity: } \\
40 \mathrm{~mol} / \mathrm{m}^{2} \mathrm{~s} \\
\text { Culture period: } 49 \text { days }\end{array}$ & [155] \\
\hline $\begin{array}{c}\text { Stevia } \\
\text { rebudiana (Bertoni) } \\
\text { Bertoni }\end{array}$ & Plantlets & $\begin{array}{l}\text { Polyphenolics and } \\
\text { Steviol Glycosides }\end{array}$ & $\begin{array}{c}\text { MS media + } \\
\text { gibberellic acid (GA3; } \\
0.5,1.0,1.5 \text { and } \\
2.0 \mathrm{mg} / \mathrm{L} \text { ) and } \\
0.5 \mathrm{mg} / \mathrm{L} \text { NAA }\end{array}$ & Gibberellic acid (GA3) & $\begin{array}{l}\text { The highest TFC accumulation } \\
\text { was shown by } 2.0 \mathrm{mg} / \mathrm{L} \text { of } \\
\mathrm{GA} 3 \text {, as compared to the } \\
\text { control culture }(4.74 \mathrm{mg} \mathrm{QE} / \mathrm{g} \\
\text { dry weight on day } 30 \text { and } \\
\text { maximum stevioside content } \\
\text { (7.13 } \mathrm{mg} / \mathrm{g} \text { dry weight) } \mathrm{w} \\
\mathrm{GA3} \text {, as compared to the } \\
\text { control culture } 3.39 \mathrm{mg} / \mathrm{g} \text { dry } \\
\text { weight. }\end{array}$ & - & $\begin{array}{l}2.0 \mathrm{mg} / \mathrm{L} \text { of GA3 was } \\
\text { optimum concentration } \\
\text { for maximum biomass } \\
\text { biosynthesis } \\
\text { (13.12 } \mathrm{g} / \text { flask) noticed } \\
\text { in exponential phase on } \\
27 \text { th day of culture. } \\
\text { Culture period: } 30 \text { days }\end{array}$ & [156] \\
\hline
\end{tabular}


Table 1. Cont.

\begin{tabular}{|c|c|c|c|c|c|c|c|c|}
\hline Plant & Explant Used & Valuable Compound & $\begin{array}{l}\text { Culture Conditions } \\
\text { and PGRs }\end{array}$ & Elicitation Strategy & $\begin{array}{l}\text { Increase in Yield of } \\
\text { Valuable Compound }\end{array}$ & Bioreactor Employed & $\begin{array}{c}\text { Optimization Strategy } \\
\text { of Culture Conditions } \\
\text { and Bioreactor }\end{array}$ & Reference \\
\hline $\begin{array}{l}\text { Talinum paniculatum } \\
\text { Ruiz and Pav }\end{array}$ & shoot & Saponin & MS media $+10 \mu \mathrm{M} \mathrm{IBA}$ & MeJA and SA & $\begin{array}{c}\text { By treatment with } 0.2 \\
\text { mM MeJA and SA, } \\
\text { saponin production } \\
\text { increased by } 1.5 \text { and } \\
1.3 \text {-fold. }\end{array}$ & - & $\begin{array}{l}\text { Culture period: } 28 \text { days } \\
\text { Sucrose: } 30 \mathrm{~g} / \mathrm{L}\end{array}$ & [157] \\
\hline $\begin{array}{l}\text { Talinum paniculatum } \\
\text { Ruiz and Pav }\end{array}$ & Leaf explants & saponin & $\underset{\text { IBA }}{\text { MS media }+2 \mathrm{mg} / \mathrm{L}}$ & - & $\begin{array}{l}\text { Saponin content was } \\
\text { increased by } \\
\text { combination of aeration } \\
\text { rate of } 0.5 \mathrm{vvm} \text { and } \\
\text { inoculum density of } \\
1 \mathrm{~g} / 400 \mathrm{~mL}\end{array}$ & $\begin{array}{l}\text { Balloon type bubble } \\
\text { bioreactor }\end{array}$ & $\begin{array}{l}\text { Aeration rate: } 0.25,0.5 \\
\text { and } 0.75 \mathrm{vvm} \\
\text { Inoculum density: } 0.5, \\
1,2 \mathrm{~g} / 400 \mathrm{~mL} \text {. } \\
\text { Culture period: } 14 \text { days }\end{array}$ & [22] \\
\hline $\begin{array}{l}\text { Tripterygium wilfordii } \\
\text { Hook. f., }\end{array}$ & Leaf & celastrol & $\begin{array}{l}\text { 1/2 MS media + } 0.25 \\
\mathrm{mg} / \mathrm{L} \text { indole-3-butyric } \\
\text { Acid and } 0.25 \mathrm{mg} / \mathrm{L} \\
\text { naphthylacetic acid }\end{array}$ & $\begin{array}{c}\text { Methyl jasmonate } \\
\text { (MeJA) and salicylic } \\
\text { acid (SA) }\end{array}$ & $\begin{array}{c}100 \mu \mathrm{M} \text { MeJA } \\
\text { significantly increased } \\
\text { celastrol content in } \\
\text { adventitious roots to } \\
6321.27 \mu \mathrm{g} / \mathrm{g} \text { dry } \\
\text { weight }\end{array}$ & - & $\begin{array}{c}\text { Sucrose: } 30 \mathrm{~g} / \mathrm{L} \\
\text { Photoperiod: } 16 / 8 \mathrm{~h} \\
\text { (day /night) } \\
\text { Culture period: } \\
6 \text { weeks }\end{array}$ & [158] \\
\hline $\begin{array}{l}\text { Withania somniffera (L.) } \\
\text { Dunal }\end{array}$ & Leaf & Withanolides & $\begin{array}{c}\frac{1}{2} \mathrm{MS} \text { media }+ \\
0.5 \mathrm{mg} / \mathrm{L} \mathrm{IBA}, 0.1 \mathrm{mg} / \mathrm{L} \\
\text { IAA }\end{array}$ & $\begin{array}{l}\text { Methyl jasmonate and } \\
\text { salicylic acid }\end{array}$ & $\begin{array}{c}150 \mu \mathrm{M} \mathrm{SA} \text { for } 4 \mathrm{~h} \\
\text { elicitor exposure period } \\
\text { resulted in the increase } \\
\text { production of } \\
\text { withanolide A (48-fold), } \\
\text { B (29-fold), withaferin } \\
\text { A (20-fold), withanone } \\
\text { (37-fold 12-deoxy } \\
\text { withastramonolide } \\
\text { (nine-fold), } \\
\text { withanoside V } \\
\text { (seven-fold), } \\
\text { withanoside IV } \\
\text { (nine-fold) }\end{array}$ & - & $\begin{array}{c}\text { culture age: } 30 \text { days old } \\
\text { elicitation period: } 6 \mathrm{~h} \\
\text { Culture period: } 50 \text { days. } \\
\text { biomass: kolli hills } \\
\text { variety maximum fresh } \\
\text { weight }(11.70 \mathrm{~g}), \mathrm{dry} \\
\text { weight }(1.90 \mathrm{~g}) \\
\text { Cumbum variety } \\
\text { maximum fresh weight } \\
(11.40 \mathrm{~g}), \mathrm{dry} \text { weight } \\
(1.85 \mathrm{~g})\end{array}$ & [159] \\
\hline
\end{tabular}


Table 2. List of Hairy root culture of medicinal plant species for the production of valuable compounds by employing bioreactors or elicitation strategy.

\begin{tabular}{|c|c|c|c|c|c|c|c|c|c|}
\hline Plant Species & Strain & Explant & $\begin{array}{c}\text { Valuable } \\
\text { Compound }\end{array}$ & Media + PGRs & Elicitation Strategy & $\begin{array}{l}\text { Increase in Yield of } \\
\text { Valuable } \\
\text { Compound }\end{array}$ & $\begin{array}{l}\text { Bioreactor } \\
\text { Employed }\end{array}$ & $\begin{array}{l}\text { Optimization } \\
\text { Strategy for Culture } \\
\text { Conditions and } \\
\text { Bioreactor }\end{array}$ & References \\
\hline $\begin{array}{l}\text { Ajuga bracteosa Wall. } \\
\text { ex Benth. }\end{array}$ & $\begin{array}{l}\text { A4, LBA-9402 and } \\
\text { ARqua1. }\end{array}$ & Leaves & phytoecdysteroids & MS media no PGRs & $\begin{array}{c}\text { MeJA and } \\
\text { coronatine (Cor) }\end{array}$ & $\begin{array}{l}\text { In comparison with } \\
\text { the unelicited hairy } \\
\text { roots, MeJA doubled } \\
\text { phytoecdysteriod } \\
\text { content i.e., } 8356 \\
\mu \mathrm{g} / \mathrm{g} \text { after } 14 \text { days } \\
\text { of Elicitation. }\end{array}$ & - & $\begin{array}{c}\text { Sucrose: } 30 \mathrm{~g} / \mathrm{L} \\
\text { Solidifying } \\
\text { agent:0.8\% phytagel }\end{array}$ & [127] \\
\hline Artemisia anпиа $\mathrm{L}$. & LBA 9402 & seedlings & artemisinin & $\begin{array}{l}\text { MS media with no } \\
\text { PGRs }\end{array}$ & $\begin{array}{c}\text { MeJA } \\
\text { Fungal elicitors: } \\
\text { Alternaria alternate, } \\
\text { Curvularia limata, } \\
\text { Fusarium solani, and } \\
\text { Piriformospora } \\
\text { indica }\end{array}$ & $\begin{array}{l}\text { By using P. indica } \\
\text { artemisinin } \\
\text { production was } \\
\text { increased by } 1.97 \\
\text { times. } \\
\text { By using } \\
\text { combination of } \\
\text { MeJA and cell } \\
\text { homogenate of } \\
\text { P.indica artemisnin } \\
\text { production was } \\
\text { enhanced by } 2.44 \\
\text { times. }\end{array}$ & - & Sucrose: $30 \mathrm{~g} / \mathrm{L}$ & [160] \\
\hline $\begin{array}{c}\text { Astragulas } \\
\text { membranceus } \mathrm{L} \text {. }\end{array}$ & $\begin{array}{c}\text { Agrobacterium } \\
\text { rhizogenes LBA9402 }\end{array}$ & Leaf & Phytoalexins & $\begin{array}{l}\text { MS media with no } \\
\text { PGRs }\end{array}$ & Chitosan & $\begin{array}{l}\text { Treatment with } 100 \\
\mathrm{mg} / \mathrm{L} \text { of chitosan } \\
\text { increased yields of } \\
\text { formononetin and } \\
\text { calycosin by } 12.45- \\
\text { and } 6.17 \text {-fold. }\end{array}$ & - & $\begin{array}{l}\text { Elicitor exposure } \\
\text { time: } 24 \mathrm{~h} . \\
\text { Chitosan: } 100 \mathrm{mg} / \mathrm{L} \\
\text { Culture period: } \\
34 \text { days }\end{array}$ & [161] \\
\hline $\begin{array}{c}\text { Celastrus paniculatus } \\
\text { W. }\end{array}$ & MTCC532 & Leaf explant & Celastrol & $\begin{array}{c}\text { MS media }+ \\
0.3 \mathrm{mg} / \mathrm{L} \\
\text { IAA }\end{array}$ & $\begin{array}{l}\text { Silver nanoparticles } \\
\text { and acetosyringone }\end{array}$ & $\begin{array}{l}\text { Celastrol increased } \\
2.24 \text {-fold by } \\
\text { treatment with } 10 \\
\mu \mathrm{g} \mathrm{mL} \mathrm{L}^{-1} \text { of AgNPs } \\
\text { (48 hexposure) }\end{array}$ & - & $\begin{array}{l}\text { 3\% sucrose } \mathrm{pH} 5.8 \\
\text { Culture period: } \\
2 \text { weeks }\end{array}$ & [133] \\
\hline Echinacea purpurea L. & ATCC 43,057 & leaf explants & $\begin{array}{l}\text { Phenolics } \\
\text { Flavonoids } \\
\text { caffeic acid } \\
\text { derivatives }\end{array}$ & MS media no PGRs & $\begin{array}{l}\text { 24-epibrassinolide } \\
\text { and l-phenylalanine }\end{array}$ & $\begin{array}{l}1.0 \mathrm{mg} / \mathrm{L} 24-\mathrm{eBL} \\
\text { gave maximum } \\
\text { production of } \\
\text { phenolics, total } \\
\text { flavonoids, cichoric } \\
\text { acid, caftaric acid, } \\
\text { Echinacoside, and } \\
\text { p-coumaric acid. }\end{array}$ & - & $\begin{array}{c}\text { Culture } \\
\text { period:21 Days } \\
\text { Sucrose: } 50 \mathrm{~g} / \mathrm{L}\end{array}$ & [115] \\
\hline
\end{tabular}


Table 2. Cont.

\begin{tabular}{|c|c|c|c|c|c|c|c|c|c|}
\hline Plant Species & Strain & Explant & $\begin{array}{l}\text { Valuable } \\
\text { Compound }\end{array}$ & Media + PGRs & Elicitation Strategy & $\begin{array}{c}\text { Increase in Yield of } \\
\text { Valuable } \\
\text { Compound }\end{array}$ & $\begin{array}{l}\text { Bioreactor } \\
\text { Employed }\end{array}$ & $\begin{array}{l}\text { Optimization } \\
\text { Strategy for Culture } \\
\text { Conditions and } \\
\text { Bioreactor }\end{array}$ & References \\
\hline Eurycoma longifolia J. & $\begin{array}{l}\text { A. rhizogenes strain } \\
\text { A4 }\end{array}$ & Root & $\begin{array}{l}\text { 9-methoxycanthin-6- } \\
\text { one } \\
\text { compound }\end{array}$ & $\begin{array}{l}\text { (MS) basal media } \\
\text { with no PGRs }\end{array}$ & MeJA and SA. & $\begin{array}{c}0.1 \mathrm{mM} \text { MeJA } \\
\text { increased } \\
\text { production of } \\
\text { 9-methoxycanthin-6- } \\
\text { one up to three folds } \\
\text { as compared to } \\
\text { control. }\end{array}$ & - & $\begin{array}{c}\text { pH:4.9 } \\
\text { Culture period: } \\
12 \text { weeks } \\
\text { inoculum size: } 0.2 \mathrm{~g} \\
\text { hairy root in } 50 \mathrm{~mL} \\
\text { of MS basal media }\end{array}$ & [162] \\
\hline Gentiana scabra B. & $\begin{array}{l}\text { A. rhizogenes strains } \\
\text { ATCC15834 }\end{array}$ & Leaf & $\begin{array}{l}\text { Iridoids } \\
\text { and secoiridoids }\end{array}$ & $\begin{array}{c}\text { B5 media }+1.0 \mathrm{mg} / \mathrm{L} \\
\text { NAA, (TDZ), zeatin, } \\
\text { IBA }\end{array}$ & Acetosyringone & $\begin{array}{l}\text { Loganic acid } \\
\text { increased } 6.6-\text { fold in } \\
\text { the presence of } \\
\text { zeatin }(1 \mathrm{mg} / \mathrm{L}) \text { and } \\
\text { gentiopicroside } \\
\text { accumulation was } \\
1.8 \text { - fold higher in } \\
\text { the presence of } \\
\mathrm{NAA}, 1 \mathrm{mg} / \mathrm{L} \text { and } \\
1.0 \mathrm{mg} / \mathrm{L} \mathrm{NAA} \text { yield } \\
1.4-\text { and } 2.5-\text { fold } \\
\text { higher } \\
\text { gentiopicroside and } \\
\text { swertiamarin. }\end{array}$ & - & $\begin{array}{l}\text { Co-cultivation } \\
\text { period: } 48 \mathrm{~h} . \\
\text { Culture } \\
\text { period:8 weeks } \\
\text { pH:5.7 } \pm 0.1 \\
\text { N6, WPM, MS and } \\
\text { B5 media were } \\
\text { tested. B5 liquid } \\
\text { media was most } \\
\text { suitable }\end{array}$ & [140] \\
\hline $\begin{array}{c}\text { Hybanthus } \\
\text { enneaspermus } \mathrm{L} \text {. }\end{array}$ & $\begin{array}{l}\text { A. rhizogenes strains } \\
\text { A4, A4T, } 8196 \text { and } \\
\text { LBA } 9402\end{array}$ & $\begin{array}{l}\text { Leaf or internode } \\
\text { explants }\end{array}$ & coumarin & $\begin{array}{c}\text { MS media+ } 0.25 \\
\text { mg/L, } \\
\text { 16N-benzyladenine } \\
\text { (BA+ } 0.1 \mathrm{mg} / \mathrm{L} \\
\text { (IAA) }\end{array}$ & Acetosyringone & $\begin{array}{c}\text { Coumarin } \\
\text { accumulation } \\
\text { increased three folds } \\
\text { in the superior } \\
\text { rhizoclone of A4 } \\
\text { origin (A4-HRL-2B7) } \\
\text { (3.25 mg/g d.wt. } \\
\text { extract) as compared } \\
\text { to that in natural } \\
\text { roots. }\end{array}$ & - & $\begin{array}{l}\text { Photoperiod: } 16 \mathrm{~h} \\
\text { Culture period: } \\
4 \text { weeks }\end{array}$ & [164] \\
\hline
\end{tabular}


Table 2. Cont.

\begin{tabular}{|c|c|c|c|c|c|c|c|c|c|}
\hline Plant Species & Strain & Explant & $\begin{array}{c}\text { Valuable } \\
\text { Compound }\end{array}$ & Media + PGRs & Elicitation Strategy & $\begin{array}{l}\text { Increase in Yield of } \\
\text { Valuable } \\
\text { Compound }\end{array}$ & $\begin{array}{l}\text { Bioreactor } \\
\text { Employed }\end{array}$ & $\begin{array}{c}\text { Optimization } \\
\text { Strategy for Culture } \\
\text { Conditions and } \\
\text { Bioreactor }\end{array}$ & References \\
\hline $\begin{array}{l}\text { Panax ginseng } \\
\text { C.A.Mey. }\end{array}$ & $\begin{array}{l}\text { Agrobacterium } \\
\text { rhizogenes }\end{array}$ & Root & ginsenosides & $\underset{\text { PGRs }}{\frac{1}{2} \text { MS media + no }}$ & Tween 80 & $\begin{array}{c}\text { Coumarin } \\
\text { accumulation } \\
\text { increased three folds } \\
\text { in the superior } \\
\text { rhizoclone of A4 } \\
\text { origin (A4-HRL-2B7) } \\
\text { (3.25 mg/g d.wt. } \\
\text { extract) as compared } \\
\text { to that in natural } \\
\text { roots. }\end{array}$ & - & $\begin{array}{l}\text { sucrose: } 3 \% \\
\text { inoculum length: } \\
20 \mathrm{~mm} \text { long } \\
\text { Tween } 80: 1.2 \% \mathrm{w} / \mathrm{v} \\
\text { Culture period: } \\
4 \text { weeks }\end{array}$ & [165] \\
\hline $\begin{array}{l}\text { Panax quinquefolius } \\
\text { L. }\end{array}$ & $\begin{array}{c}\text { A.rhizogenes ATCC } \\
15834\end{array}$ & seedlings & ginsenosides & $\begin{array}{c}\text { Gamborg media + } \\
\text { no PGRs }\end{array}$ & Yeast extract & $\begin{array}{c}\text { (3 days time of } \\
\text { exposure and } 50 \\
\mathrm{mg} / \mathrm{L} \text { of } Y \mathrm{E}) \\
\text { increased total } \\
\text { ginsenoside content } \\
\text { up to } 32.25 \mathrm{mg} / \mathrm{g} \\
\text { D.W }\end{array}$ & $\begin{array}{l}\text { Nutrient sprinkle } \\
\text { Bioreactor }\end{array}$ & $\begin{array}{c}\text { Sucrose: } 30 \mathrm{~g} / \mathrm{L} \\
\text { YE: } 50 \mathrm{mg} / \mathrm{L} \\
\text { Elicitation period: } 3 \\
\text { and } 7 \text { days } \\
\text { Incubation period: } \\
5 \text { weeks }\end{array}$ & [166] \\
\hline $\begin{array}{l}\text { Panax vietnamensis } \\
\text { Ha et Grushv. }\end{array}$ & $\begin{array}{l}\text { Rhizobium rhizogenes } \\
\text { ATCC } 15,834 \text { strain }\end{array}$ & shoot explants & $\begin{array}{l}\text { Ocotillol-type } \\
\text { ginsenosides }\end{array}$ & $\underset{\text { PGRs }}{\frac{1}{2} \text { MS media + no }}$ & - & $\begin{array}{c}\text { With culture } \\
\text { conditions the PPD } \\
\text { contents evaluated } \\
\text { at } 0.57 \% \text { dry weight, } \\
\text { the PPT at } 0.028 \% \\
\text { dry weight, and the } \\
\text { OCT at } 4.3 \% \text { dry } \\
\text { weight in hairy } \\
\text { roots. }\end{array}$ & - & $\begin{array}{l}\text { Co-cultivation } \\
\text { system } \\
\text { sucrose: } 3 \%(w / v) \\
\text { culture period: } \\
90 \text { days }\end{array}$ & [167] \\
\hline $\begin{array}{l}\text { Perouskia abrotanoides } \\
\text { Karel. }\end{array}$ & $\begin{array}{c}\text { ATCC15834 } \\
\text { TR105, and R1000 }\end{array}$ & Seedlings and nodes & $\begin{array}{l}\text { Cryptotanshinone } \\
\text { and tanshinone IIA }\end{array}$ & $\begin{array}{l}\text { MS media } \\
\text { No PGR }\end{array}$ & Acetosyringone & $\begin{array}{c}\text { Transformation } \\
\text { frequency increased } \\
\text { by up to } 60.99 \% \\
\text { when } 100 \mu \mathrm{MM} \text { of } \\
\text { acetosyringone was } \\
\text { used. } \\
\text { cryptotanshinone } \\
\text { and tanshinone IIA } \\
\text { levels were } \\
53.17 \pm 0.26 \text { and } \\
14.48 \pm 0.30 \mu \mathrm{g} / \mathrm{g} \\
\text { dry weight, } \\
\text { respectively in hairy } \\
\text { roots induced by } \\
\text { TR105. }\end{array}$ & - & $\begin{array}{l}\text { Half strength MS } \\
\text { media } \\
\text { Sucrose:3\% }\end{array}$ & [152] \\
\hline
\end{tabular}


Table 2. Cont.

\begin{tabular}{|c|c|c|c|c|c|c|c|c|c|}
\hline Plant Species & Strain & Explant & $\begin{array}{c}\text { Valuable } \\
\text { Compound }\end{array}$ & Media + PGRs & Elicitation Strategy & $\begin{array}{c}\text { Increase in Yield of } \\
\text { Valuable } \\
\text { Compound }\end{array}$ & Bioreactor Employed & $\begin{array}{l}\text { Optimization } \\
\text { Strategy for Culture } \\
\text { Conditions and } \\
\text { Bioreactor }\end{array}$ & References \\
\hline Plumbago indica $\mathrm{L}$. & ATCC 15834 & Leaf explant & Plumbagin & $\begin{array}{l}\text { MS media with no } \\
\text { PGRs }\end{array}$ & $\begin{array}{c}\text { Yeast carbohydrate } \\
\text { fraction } \\
\text { Chitosan } \\
\text { Manganese chloride } \\
\text { Copper chloride and } \\
\text { MeJA }\end{array}$ & $\begin{array}{c}\text { Plumbagin } \\
\text { production was } \\
\text { enhanced to } \\
1.2-2 \text {-fold by } \\
\text { treatment with Yeast } \\
\text { carbohydrate } \\
\text { fraction, chitosan, } \\
\text { manganese chloride, } \\
\text { copper chloride and } \\
\text { MeJA. } \\
\text { With } 20 \text { days old } \\
\text { bioreactor-culture, } \\
\text { and exposure of } \\
\text { chitosan }(200 \mathrm{mg} / \mathrm{L}) \\
\text { and methyl } \\
\text { jasmonate }(80 \mu \mathrm{M}) \\
\text { plumbagin } \\
\text { production was } \\
\text { enhanced to } 13.16 \pm \\
1.72 \mathrm{mg} \mathrm{g}^{-1} \text { dry } \\
\text { weight. }\end{array}$ & $\begin{array}{c}\text { Bioreactor with } \\
\text { continuous air supply }\end{array}$ & $\begin{array}{c}\text { Bioreactor was } \\
\text { maintained in dark } \\
\text { at } 25 \pm 2{ }^{\circ} \mathrm{C} \\
\text { Sucrose: } 3 \%\end{array}$ & [168] \\
\hline $\begin{array}{c}\text { Polygonum } \\
\text { multiflorum Thunb. }\end{array}$ & $\begin{array}{l}\text { A. rhizogenes strain } \\
\text { KCCM } 11879\end{array}$ & Leaf & phenolic compounds & $\underset{\text { PGRs }}{\text { MS media }}+$ no & MeJA & $\begin{array}{l}\text { Exposure to } 50 \mu \mathrm{M} \\
\text { methyl jasmonate for } \\
5 \text { days increased } \\
\text { levels of phenolic } \\
\text { compounds more } \\
\text { than } 2.5 \text {-fold. }\end{array}$ & - & $\begin{array}{c}\text { Sucrose: } 3 \% \\
\text { Inoculum density: } \\
0.5 \mathrm{~g} / 100 \mathrm{~mL} \\
\text { Culture period: } \\
21 \text { days }\end{array}$ & [88] \\
\hline Prunella vulgaris L., & $\begin{array}{l}\text { A. rhizogenes } \\
\text { (ATCC15834) }\end{array}$ & Leaf & Rosmarinic acid & $\begin{array}{l}\text { MS media + no } \\
\text { PGRs }\end{array}$ & Ethephon and SA & $\begin{array}{l}\text { Rosmarinic acid } \\
\text { accumulation } \\
\text { increased by } \\
\text { 1.66-fold } 8 \text { days after } \\
\text { Eth elicitation and } \\
1.48 \text {-fold } 2 \text { days } \\
\text { post-SA addition. }\end{array}$ & - & $\begin{array}{c}\text { Sucrose: } 3 \% \\
\text { Elicitation period: } 8 \\
\text { days } \\
\text { Culture period: } \\
30 \text { days }\end{array}$ & [169] \\
\hline $\begin{array}{c}\text { Stevia } \\
\text { rebudiana (Bertoni) } \\
\text { Bertoni }\end{array}$ & A4 strain & Nodal explant & Steviosides & $\begin{array}{c}\text { MS media + BAP } \\
(0.5-2.0 \mathrm{mg} / \mathrm{L}) 0.5 \\
\mathrm{mg} \mathrm{NAA}\end{array}$ & Light & $\begin{array}{c}\text { Stevioside contents } \\
\text { in the SRA4 HR } \\
\text { clone on day } 75 \text { th } \\
\text { increased } 0.247 \pm \\
0.011 \text { to } 1.72 \pm 0.052 \\
\mathrm{mg} / \mathrm{g} \text { dry weight in } \\
\text { the root tissues and } \\
0.097 \pm 0.072 \text { to } 2.12 \\
\pm 0.06 \mathrm{mg} / \mathrm{L} \text { in the } \\
\text { media under light } \\
\text { conditions }\end{array}$ & - & $\begin{array}{c}\text { co-cultivation } \\
\text { period:2-3 days } \\
\text { culture period: } 75 \\
\text { days } \\
\text { agitation rate: } 80 \\
\text { rpm } \\
\frac{1}{2} \mathrm{MS} \text { Media }+1.0 \\
\mathrm{mg} / \mathrm{LBAP}+ \\
0.1 \mathrm{mg} / \mathrm{L} \text { NAA }\end{array}$ & [170] \\
\hline
\end{tabular}


Table 2. Cont.

\begin{tabular}{|c|c|c|c|c|c|c|c|c|c|}
\hline Plant Species & Strain & Explant & $\begin{array}{c}\text { Valuable } \\
\text { Compound }\end{array}$ & Media + PGRs & Elicitation Strategy & $\begin{array}{l}\text { Increase in Yield of } \\
\text { Valuable } \\
\text { Compound }\end{array}$ & $\begin{array}{l}\text { Bioreactor } \\
\text { Employed }\end{array}$ & $\begin{array}{l}\text { Optimization } \\
\text { Strategy for Culture } \\
\text { Conditions and } \\
\text { Bioreactor }\end{array}$ & References \\
\hline $\begin{array}{l}\text { Talinum paniculatum } \\
\text { Ruiz and Pav }\end{array}$ & LB510 & Leaves & saponin & $\begin{array}{l}\text { MS media with no } \\
\text { PGRs }\end{array}$ & - & $\begin{array}{c}\text { MS medium } \\
\text { supplemented with } \\
5 \% \text { sucrose and } 2.0 \\
\text { strength potassium } \\
\text { nitrate of MS, } \\
\text { produced the } \\
\text { maximum saponin } \\
\text { content. }\end{array}$ & $\begin{array}{l}\text { balloon-type bubble } \\
\text { bioreactor }\end{array}$ & $\begin{array}{c}\text { Inoculum density: } \\
2 \mathrm{~g} / 400 \mathrm{~mL} \\
\text { Aeration rate: } \\
0.25 \mathrm{vvm} \\
\text { Culture } \\
\text { period:14 days }\end{array}$ & [171] \\
\hline $\begin{array}{l}\text { Valerian jatamansi } \\
\text { Jones. }\end{array}$ & R1601 & Young Leaves & Valtrate & $\begin{array}{l}\text { MS media } \\
\text { No PGR }\end{array}$ & $\begin{array}{l}\mathrm{MeJA} \\
\text { JA } \\
\text { SA }\end{array}$ & $\begin{array}{l}\text { By treatment with } \\
100 \mathrm{mg} / \mathrm{L} \text { MeJA, } \\
\text { production of } \\
\text { Valtrate was } \\
\text { increased to a level } \\
\text { of } 3.63 \text { times, which } \\
\text { was higher than } \\
\text { non-elicited control. }\end{array}$ & - & $\begin{array}{c}\mathrm{pH}: 5.9 \\
\text { Subculturing of } \\
\text { hairy roots after } \\
\text { every } 5 \text { weeks. }\end{array}$ & [172] \\
\hline $\begin{array}{l}\text { Withania sominefera } \\
\text { (L.) Dunal }\end{array}$ & $\begin{array}{c}\text { Agrobacterium } \\
\text { tumefaciens C58C1 } \\
\text { (pRiA4) }\end{array}$ & Leaf & Withaferin A & $\begin{array}{c}\frac{1}{2} \text { MS media + no } \\
\text { PGRs }\end{array}$ & - & $\begin{array}{c}\text { WFA in THRs } \\
\text { contain } 1.51 \text {-fold } \\
\text { more WFA (330 } \pm \\
0.87 \mu \mathrm{g} / \mathrm{g} \text { dry } \\
\text { weight }(\text { dry weight)) } \\
\text { than AHRs }(218 \pm \\
0.17 \mu \mathrm{g} / \mathrm{g} \mathrm{dry} \\
\text { weight) }\end{array}$ & - & $\begin{array}{l}\text { culture period: } \\
40 \text { days } \\
\text { biomass doubling } \\
\text { time of THRs and } \\
\text { AHRs: } 18 \text { and } \\
30 \text { days }\end{array}$ & [173] \\
\hline
\end{tabular}




\section{Conclusions}

The expeditious advancement in biotechnology has offered adventitious and hairy root cultures as one of the best alternatives to whole plant cultivation for the production of valuable compounds by employing medicinal plants. Plethora of studies has been conducted with the aim to produce valuable compounds by utilizing hairy and adventitious root cultures that have made enormous advances in plant sciences. For maximum production of specific bioactive compounds in these systems, optimization of culture conditions, elicitation strategies, precursor feeding, and various other approaches have been reported in numerous studies. A promising alternative to field cultivation of medicinal plants is adventitious or hairy root culture in a bioreactor system supplied with an elicitor. The commercial exploitation of bioactive substances requires scaling up these approaches utilizing bioreactors. Optimized use of these approaches, either individually or in combination, can provide synergistic effects, resulting in increased biomass productivity and bioactive compounds accumulation. Nevertheless, both chemical and physical optimization is foremost to produce high-quality yields. Furthermore, profound knowledge of biosynthetic pathways of desired compounds in adventitious and hairy roots is still in its early stages. To improve yields metabolic engineering offers an encouraging outlook but requires the understanding of governance on secondary metabolic pathways embroiled on the levels of genes, enzymes, and products including details such as compartmentation and transport is required.

Author Contributions: Conceptualization, M.J.H.; methodology, M.J.H., Y.A., N.N. and S.F; validation, B.H.A., C.H. and S.D.; formal analysis, Y.A.; investigation, B.H.A.; resources, B.H.A.; data curation, Y.A.; writing—original draft preparation, M.J.H.; writing—review and editing, M.J.H., Y.A., N.N. and S.F.; visualization, M.J.H.; supervision, B.H.A.; project administration, M.J.H. and B.H.A.; funding acquisition, C.H. and B.H.A. All authors have read and agreed to the published version of the manuscript.

Funding: This research was funded by Région Centre-Val de Loire (VALBIOCOSM 17019UNI) and Campus France.

Institutional Review Board Statement: Not applicable.

Informed Consent Statement: Not applicable.

Data Availability Statement: All the data are included in the present study.

Acknowledgments: This research was supported by Cosmetosciences, a global training and research program dedicated to the cosmetic industry. Located in the heart of the Cosmetic Valley, this program led by University of Orléans is funded by the Région Centre-Val de Loire (VALBIOCOSM 17019UNI). B.H.A. and C.H. acknowledge Le Studium-Institute for Advanced Studies, Loire Valley, Orléans, France, and Campus France (Peridot program).

Conflicts of Interest: The authors declare no conflict of interest.

\section{References}

1. Chen, S.L.; Yu, H.; Luo, H.M.; Wu, Q.; Li, C.F.; Steinmetz, A. Conservation and sustainable use of medicinal plants: Problems, progress, and prospects. Chin. Med. 2016, 11, 1-10. [CrossRef] [PubMed]

2. Wang, J.; Li, J.L.; Li, J.; Li, J.X.; Liu, S.J.; Huang, L.Q.; Gao, W.Y. Production of active compounds in medicinal plants: From plant tissue culture to biosynthesis. Chin. Herb. Med. 2017, 9, 115-125. [CrossRef]

3. Isah, T.; Umar, S.; Mujib, A.; Sharma, M.P.; Rajasekharan, P.E.; Zafar, N.; Frukh, A. Secondary metabolism of pharmaceuticals in the plant in vitro cultures: Strategies, approaches, and limitations to achieving higher yield. Plant Cell Tissue Organ Cult. 2018, 132, 239-265. [CrossRef]

4. Kundu, S.; Salma, U.; Gantait, S. Cryopreservation of Medicinal Herbs: Major Breakthroughs, Hurdles and Future. In Biotechnological Approaches for Medicinal and Aromatic Plants; Springer: Berlin/Heidelberg, Germany, 2018; pp. $353-381$.

5. Yang, L.; Wen, K.S.; Ruan, X.; Zhao, Y.X.; Wei, F.; Wang, Q. Response of plant secondary metabolites to environmental factors. Molecules 2018, 23, 762. [CrossRef]

6. Yu, K.W.; Murthy, H.N.; Jeong, C.S.; Hahn, E.J.; Paek, K.Y. Organic germanium stimulates the growth of ginseng adventitious roots and ginsenoside production. Process. Biochem. 2005, 40, 2959-2961. [CrossRef] 
7. Sui, Q.; Jiang, C.; Yu, D.; Chen, M.; Zhang, J.; Wang, Y.; Wei, Y. Performance of a sequencing-batch membrane bioreactor (SMBR) with an automatic control strategy treating high-strength swine wastewater. J. Hazard. Mater. 2018, 342, 210-219. [CrossRef]

8. Paek, K.Y.; Murthy, H.N.; Hahn, E.J.; Zhong, J.J. Large scale culture of ginseng adventitious roots for production of ginsenosides. Adv. Biochem. Eng. Biotechnol. 2009, 113, 151-176.

9. Sivakumar, G.; Yu, K.; Paek, K. Production of biomass and ginsenosides from adventitious roots of Panax ginseng in bioreactor cultures. Eng. Life Sci. 2005, 5, 333-342. [CrossRef]

10. Habibi, P.; De Sa, M.F.G.; Makhzoum, A.; Malik, S.; da Silva, A.L.L.; Hefferon, K.; Soccol, C.R. Bioengineering hairy roots: Phytoremediation, secondary metabolism, molecular pharming, plant-plant interactions and biofuels. Sustain. Agric. Rev. 2017, $22,213$.

11. Ahmar, S.; Gill, R.A.; Jung, K.H.; Faheem, A.; Qasim, M.U.; Mubeen, M.; Zhou, W. Conventional and molecular techniques from simple breeding to speed breeding in crop plants: Recent advances and future outlook. Int. J. Mol. Sci. 2020, 21, 2590. [CrossRef]

12. Ncube, E.N.; Steenkamp, P.A.; Madala, N.E.; Dubery, I.A. Metabolite profiling of the undifferentiated cultured cells and differentiated leaf tissues of Centella asiatica. Plant Cell Tissue Organ Cult. 2017, 129, 431-443. [CrossRef]

13. Deepthi, S.; Satheeshkumar, K. Effects of major nutrients, growth regulators and inoculum size on enhanced growth and camptothecin production in adventitious root cultures of Ophiorrhiza mungos L. Biochem. Eng. J. 2017, 117, 198-209. [CrossRef]

14. Murthy, H.N.; Dandin, V.S.; Paek, K.Y. Tools for biotechnological production of useful phytochemicals from adventitious root cultures. Phytochem. Rev. 2016, 15, 129-145. [CrossRef]

15. Gantet, P.; Imbault, N.; Thiersault, M.; Doireau, P. Necessity of a functional octadecanoic pathway for indole alkaloid synthesis by Catharanthus roseus cell suspensions cultured in an auxin-starved medium. Plant Cell Physiol. 1998, 39, 220-225. [CrossRef]

16. Carvalho, E.B.; Curtis, W.R. Characterization of fluid-flow resistance in root cultures with a convective flow tubular bioreactor. Biotechnol. Bioeng. 1998, 60, 375-384. [CrossRef]

17. Sudha, C.G.; Seeni, S. Establishment and analysis of fast-growing normal root culture of Decalepis arayalpathra, a rare endemic medicinal plant. Curr. Sci. 2001, 81, 371-374.

18. Guillon, S.; Trémouillaux-Guiller, J.; Pati, P.K.; Rideau, M.; Gantet, P. Harnessing the potential of hairy roots: Dawn of a new era. TRENDS Biotechnol. 2006, 24, 403-409. [CrossRef]

19. Liu, C.Z.; Abbasi, B.H.; Gao, M.; Murch, S.J.; Saxena, P.K. Caffeic acid derivatives production by hairy root cultures of Echinacea purpurea. J. Agric. Food Chem. 2006, 54, 8456-8460. [CrossRef]

20. Pistelli, L.; Giovannini, A.; Ruffoni, B.; Bertoli, A.; Pistelli, L. Hairy root cultures for secondary metabolites production. Adv. Exp. Med. Biol. 2010, 698, 167-184.

21. Parsons, J.L.; Cameron, S.I.; Harris, C.S.; Smith, M.L. Echinacea biotechnology: Advances, commercialization and future considerations. Pharm. Biol. 2018, 56, 485-494. [CrossRef]

22. Roy, A. Hairy Root Culture an Alternative for Bioactive Compound Production from Medicinal Plants. Curr. Pharm. Biotechnol. 2021, 22, 136-149. [CrossRef] [PubMed]

23. Miao, G.P.; Han, J.; Zhang, J.F.; Zhu, C.S.; Zhang, X. A MDR transporter contributes to the different extracellular production of sesquiterpene pyridine alkaloids between adventitious root and hairy root liquid cultures of Tripterygium wilfordii Hook. f. Plant Mol. Biol. 2017, 95, 51-62. [CrossRef] [PubMed]

24. Choi, S.M.; Son, S.H.; Yun, S.R.; Kwon, O.W.; Seon, J.H.; Paek, K.Y. Pilot-scale culture of adventitious roots of ginseng in a bioreactor system. Plant Cell Tissue Organ Cult. 2000, 62, 187-193. [CrossRef]

25. Baque, M.A.; Moh, S.H.; Lee, E.J.; Zhong, J.J.; Paek, K.Y. Production of biomass and useful compounds from adventitious roots of high-value added medicinal plants using bioreactor. Biotechnol. Adv. 2012, 30, 1255-1267. [CrossRef]

26. Park, Y.G.; Kim, S.J.; Kang, Y.M.; Jung, H.Y.; Prasad, D.T.; Kim, S.W.; Choi, M.S. Production of ginkgolides and bilobalide from optimized theGinkgo biloba cell culture. Biotechnol. Bioprocess Eng. 2004, 9, 41-46. [CrossRef]

27. Yusuf, N.A.; Rahim, N.S.M.; Azhar, S.Z.A.; Ghani, K.A.; Sommano, S.; Khalid, N. Adventitious root cultures of Boesenbergia rotunda as a source of Pinostrobin. Int. J. Adv. Sci. Eng. IT 2018, 8, 377-383. [CrossRef]

28. Kim, Y.D.; Kim, H.G.; Kim, J.C.; Sim, S.J.; Min, J.Y.; Hwang, J.G.; Choi, M.S. Effects of culture media on catechins and caffeine production in adventitious roots of tea tree (Camellia sinensis L.). Agric. Life Sci. Res. 2013, 47, 11-20.

29. Wu, C.H.; Tewari, R.K.; Hahn, E.J.; Paek, K.Y. Nitric oxide elicitation induces the accumulation of secondary metabolites and antioxidant defense in adventitious roots of Echinacea purpurea. J. Plant Biol. 2007, 50, 636-643. [CrossRef]

30. Lee, Y.S.; Yang, T.J.; Park, S.U.; Baek, J.H.; Wu, S.; Lim, K.B. Induction and Proliferation of Adventitious Roots from 'Aloe vera' Leaf Tissues for 'In Vitro' Production of Aloe-Emodin. Plant Omics 2011, 4, 190-194.

31. Lee, Y.S.; Ju, H.K.; Kim, Y.J.; Lim, T.G.; Uddin, M.R.; Kim, Y.B.; Yang, T.J. Enhancement of anti-inflammatory activity of Aloe vera adventitious root extracts through the alteration of primary and secondary metabolites via salicylic acid elicitation. PLoS ONE 2013, 8, e82479. [CrossRef]

32. Khalafalla, M.M.; Daffalla, H.M.; El-Shemy, H.A.; Abdellatef, E. Establishment of in vitro fast-growing normal root culture of Vernonia amygdalina-A potent African medicinal plant. Afr. J. Biotechnol. 2009, 8, 5952-5957.

33. Hussein, S.; Ling, A.P.K.; Ng, T.H.; Ibrahim, R.; Paek, K.Y. Adventitious roots induction of recalcitrant tropical woody plant, Eurycoma longifolia. Rom. Biotechnol. Lett. 2012, 17, 7027.

34. Hahn, E.J.; Kim, Y.S.; Yu, K.W.; Jeong, C.S.; Paek, K.Y. Adventitious root cultures of Panax ginseng CV Meyer and ginsenoside production through large-scale bioreactor system. J. Plant Biotechnol. 2003, 5, 1-6. 
35. Praveen, N.; Manohar, S.H.; Naik, P.M.; Nayeem, A.; Jeong, J.H.; Murthy, H.N. Production of andrographolide from adventitious root cultures of Andrographis paniculata. Curr. Sci. 2009, 96, 694-697.

36. Manokari, M.; Shekhawat, M.S. Implications of auxins in induction of adventitious roots from leaf explants of cannon ball tree (Couroupita guianensis Aubl.). World Sci. News 2016, 33, 109-121.

37. Li, X.; Chen, L.; Forde, B.G.; Davies, W.J. The biphasic root growth response to abscisic acid in Arabidopsis involves interaction with ethylene and auxin signalling pathways. Front. Plant Sci. 2017, 8, 1493. [CrossRef] [PubMed]

38. Baque, M.A.; Hahn, E.J.; Paek, K.Y. Growth, secondary metabolite production and antioxidant enzyme response of Morinda citrifolia adventitious root as affected by auxin and cytokinin. Plant Biotechnol. Rep. 2010, 4, 109-116. [CrossRef]

39. Ling, A.K.; Kok, K.M.; Hussein, S.; Ong, S.L. Effects of plant growth regulators on adventitious roots induction from different explants of Orthosiphon stamineus. Am.-Eurasian J. Sustain. Agric. 2009, 3, 493-501.

40. Lee, E.J.; Mobin, M.; Hahn, E.J.; Paek, K.Y. Effects of sucrose, inoculum density, auxins, and aeration volume on ceil growth of Gymnema sylvestre. J. Plant Biol. 2006, 49, 427-431. [CrossRef]

41. Wu, C.H.; Dewir, Y.H.; Hahn, E.J.; Paek, K.Y. Optimization of culturing conditions for the production of biomass and phenolics from adventitious roots of Echinacea angustifolia. J. Plant Biol. 2006, 49, 193-199. [CrossRef]

42. Kim, Y.S.; Hahn, E.J.; Yeung, E.C.; Paek, K.Y. Lateral root development and saponin accumulation as affected by IBA or NAA in adventitious root cultures of Panax ginseng CA Meyer. Vitr. Cell. Dev. Biol.-Plant 2003, 39, 245-249. [CrossRef]

43. Kollárová, K.; Lišková, D.; Kákoniová, D.; Lux, A. Effect of auxins on Karwinskia humboldtiana root cultures. Plant Cell Tissue Organ Cult. 2004, 79, 213-221. [CrossRef]

44. Zhou, X.; Zhong, J.J. Plant cell culture, secondary product accumulation. Encycl. Ind. Biotechnol. Bioprocess Biosep. Cell Technol. 2010, 7, 1-28.

45. Rao, R.S.; Ravishankar, A.G. Plant cell cultures: Chemical factories of secondary metabolites. Biotechnol. Adv. 2002, 20, 101-153.

46. Liu, C.Z.; Guo, C.; Wang, Y.C.; Ouynag, F. Effect of light irradiation on hairy root growth and artemisinin biosynthesis of Artemisia annua L. Process. Biochem. 2002, 38, 581-585. [CrossRef]

47. Kakegawa, K.; Hattori, E.; Koike, K.; Takeda, K. Induction of anthocyanin synthesis and related enzyme activities in cell cultures of Centaurea cyanus by UV-light irradiation. Phytochemistry 1991, 30, 2271-2273. [CrossRef]

48. Mulder-Krieger, T.; Verpoorte, R.; Svendse, A.; Cheffer, J. Production of essential oils and flavours in plant cell and tissue cultures. A review. Plant Cell Tissue Organ Cult. 1988, 13, 85-154. [CrossRef]

49. Jeong, C.S.; Murthy, H.N.; Hahn, E.J.; Lee, H.L.; Paek, K.Y. Inoculum size and auxin concentration influence the growth of adventitious roots and accumulation of ginsenosides in suspension cultures of ginseng (Panax ginseng CA Meyer). Acta Physiol. Plant. 2009, 31, 219-222. [CrossRef]

50. Chattopadhyay, S.; Farkya, S.; Srivastava, K.A.; Bisaria, S.V. Bioprocess. considerations for production of secondary metabolites by plant cell suspension cultures. Biotechnol. Bioprocess Eng. 2002, 7, 138-149. [CrossRef]

51. Verpoorte, R.; Contin, A.; Memelink, J.; Contin, A.; Memelink, J. Biotechnology for the production of plant secondary metabolites. Phytochem. Rev. 2002, 1, 13-25. [CrossRef]

52. Hwang, S.J.; Kim, K.S.; Pyo, B.S.; Hwang, B. Saponin production by hairy root cultures of Panax ginseng CA Meyer: Influence of PGR and polyamines. Biotechnol. Bioprocess Eng. 1999, 4, 309-312. [CrossRef]

53. Dicosmo, F.; Misawa, M. Plant cell and tissue culture: Alternatives for metabolite production. Biotechnol. Adv. 1995, 13, 425-453. [CrossRef]

54. Georgiev, M.I.; Weber, J.; Maciuk, A. Bioprocessing of plant cell cultures for mass production of targeted compounds. Appl. Microbiol. Biotechnol. 2009, 83, 809-823. [CrossRef] [PubMed]

55. Shakya, P.; Marslin, G.; Siram, K.; Beerhues, L.; Franklin, G. Elicitation as a tool to improve the profiles of high-value secondary metabolites and pharmacological properties of Hypericum perforatum. J. Pharm. Pharmacol. 2019, 71, 70-82. [CrossRef] [PubMed]

56. Akula, R.; Ravishankar, G.A. Influence of abiotic stress signals on secondary metabolites in plants. Plant Signal. Behav. 2011, 6, 1720-1731. [CrossRef] [PubMed]

57. Seybold, H.; Trempel, F.; Ranf, S.; Scheel, D.; Romeis, T.; Lee, J. Ca ${ }_{2+}$ signalling in plant immune response: From pattern recognition receptors to $\mathrm{Ca}_{2+}$ decoding mechanisms. New Phytol. 2014, 204, 782-790. [CrossRef]

58. Naoumkina, M.A.; He, X.; Dixon, R.A. Elicitor-induced transcription factors for metabolic reprogramming of secondary metabolism in Medicago truncatula. BMC Plant Biol. 2008, 8, 1-14. [CrossRef]

59. Bolwell, G.P.; Wojtaszek, P. Mechanisms for the generation of reactive oxygen species in plant defence-A broad perspective. Physiol. Mol. Plant Pathol. 1997, 51, 347-366. [CrossRef]

60. Peebles, C.A.; Hughes, E.H.; Shanks, J.V.; San, K.Y. Transcriptional response of the terpenoid indole alkaloid pathway to the overexpression of ORCA3 along with jasmonic acid elicitation of Catharanthus roseus hairy roots over time. Metab. Eng. 2009, 11, 76-86. [CrossRef]

61. Thakur, M.; Bhattacharya, S.; Khosla, P.K.; Puri, S. Improving production of plant secondary metabolites through biotic and abiotic elicitation. J. Appl. Res. Med. Aromat. Plants 2019, 12,1-12. [CrossRef]

62. Shibuya, N.; Minami, E. Oligosaccharide signalling for defence responses in plant. Physiol. Mol. Plant Pathol. 2001, 59, 223-233. [CrossRef]

63. Mueller, M.J.; Brodschelm, W.; Spannagl, E.; Zenk, M.H. Signaling in the elicitation process is mediated through the octadecanoid pathway leading to jasmonic acid. Proc. Natl. Acad. Sci. USA 1993, 90, 7490-7494. [CrossRef] [PubMed] 
64. Cai, Z.; Kastell, A.; Speiser, C.; Smetanska, I. Enhanced resveratrol production in Vitis vinifera cell suspension cultures by heavy metals without loss of cell viability. Appl. Biochem. Biotechnol. 2013, 171, 330-340. [CrossRef]

65. Anasori, P.; Asghari, G. Effects of light and differentiation on gingerol and zingiberene production in callus culture of Zingiber officinale Rosc. Res. Pharm. Sci. 2008, 3, 59-63.

66. Kumari, R.S.B.; Agrawal, S.; Singh, N.K.D. Supplemental ultraviolet-B induced changes in essential oil composition and total phenolics of Acorus calamus L. (sweet flag). Ecotoxicol. Environ. Saf. 2009, 72, 2013-2019. [CrossRef] [PubMed]

67. Griffith, M.; Yaish, M.W.F. Antifreeze proteins in overwintering plants: A tale of two activities. Trends Plant Sci. 2004, 9, 399-405. [CrossRef]

68. Zobayed, S.M.A.; Afreen, F.; Kozai, T. Phytochemical and physiological changes in the leaves of St. John's wort plants under a water stress condition. Environ. Exp. Bot. 2007, 59, 109-116. [CrossRef]

69. Hayat, Q.; Hayat, S.; Irfan, M.; Ahmad, A. Effect of exogenous salicylic acid under changing environment: A review. Environ. Exp. Bot. 2010, 68, 14-25. [CrossRef]

70. Zhang, B.; Zheng, L.P.; Yi Li, W.; Wen Wang, J. Stimulation of artemisinin production in Artemisia annua hairy roots by Ag-SiO2 core-shell nanoparticles. Curr. Nanosci. 2013, 9, 363-370. [CrossRef]

71. Ghanati, F.; Bakhtiarian, S. Effect of methyl jasmonate and silver nanoparticles on production of secondary metabolites by Calendula officinalis L (Asteraceae). Trop. J. Pharm. Res. 2014, 13, 1783-1789. [CrossRef]

72. Sharafi, E.; Fotokian, M.H.; Loo, H. Improvement of hypericin and hyperforin production using zinc and iron nano-oxides as elicitors in cell suspension culture of John'swort (Hypericum perforatum L). J. Med. Plants By-Prod. 2013, 2, 177-184.

73. Raei, M.; Angaji, S.A.; Omidi, M.; Khodayari, M. Effect of abiotic elicitors on tissue culture of Aloe vera. Int. J. Biosci. 2014, 5, 74-81.

74. Zhong, J.J. Biochemical engineering of the production of plant-specific secondary metabolites by cell suspension cultures. Adv. Biochem. Eng. Biotechnol. 2001, 72, 1-26. [PubMed]

75. Zhong, J.J.; Pan, Z.W.; Wang, Z.Y.; Wu, J.; Chen, F.; Takagi, M.; Yoshida, T. Effect of mixing time on taxoid production using suspension cultures of Taxus chinensis in a centrifugal impeller bioreactor. J. Biosci. Bioeng. 2002, 94, 244-250. [CrossRef]

76. Dörnenburg, H.; Knorr, D. Strategies for the improvement of secondary metabolite production in plant cell cultures. Enzym. Microb. Technol. 1995, 17, 674-684. [CrossRef]

77. Chiou, S.Y.; Sung, J.M.; Huang, P.W.; Lin, S.D. Antioxidant, antidiabetic, and antihypertensive properties of Echinacea purpurea flower extract and caffeic acid derivatives using in vitro models. J. Med. Food 2017, 20, 171-179. [CrossRef]

78. Smart, N.J.; Fowler, M.W. Effect of aeration on large-scale cultures of plant cells. Biotechnol. Lett. 1981, 3, 171-176. [CrossRef]

79. Lv, L.; Shao, X.I.; Wang, L.; Huang, D.; Ho, C.T.; Sang, S. Stilbene glucoside from Polygonum multiflorum Thunb.: A novel natural inhibitor of advanced glycation end product formation by trapping of methylglyoxal. J. Agric. Food Chem. 2010, 58, $2239-2245$. [CrossRef]

80. Lv, L.; Cheng, Y.; Zheng, T.; Li, X.; Zhai, R. Purification, antioxidant activity and antiglycation of polysaccharides from Polygonum multiflorum Thunb. Carbohydr. Polym. 2014, 99, 765-773. [CrossRef]

81. Ho, T.T.; Jeong, C.S.; Lee, H.; Park, S.Y. Effect of explant type and genotype on the accumulation of bioactive compounds in adventitious root cultures of Polygonum multiflorum. Plant Cell Tissue Organ Cult. 2019, 137, 115-124. [CrossRef]

82. Han, M.N.; Lu, J.M.; Zhang, G.Y.; Yu, J.; Zhao, R.H. Mechanistic studies on the use of Polygonum multiflorum for the treatment of hair graying. BioMed Res. Int. 2015, 2015, 651048. [CrossRef] [PubMed]

83. Wu, C.H.; Murthy, H.N.; Hahn, E.J.; Paek, K.Y. Establishment of adventitious root co-culture of Ginseng and Echinacea for the production of secondary metabolites. Acta Physiol. Plant. 2008, 30, 891-896. [CrossRef]

84. Lee, E.J.; Park, S.Y.; Paek, K.Y. Enhancement strategies of bioactive compound production in adventitious root cultures of Eleutherococcus koreanum Nakai subjected to methyl jasmonate and salicylic acid elicitation through airlift bioreactors. Plant Cell Tissue Organ Cult. 2015, 120, 1-10. [CrossRef]

85. Murthy, H.N.; Praveen, N. Carbon sources and medium pH affects the growth of Withania somnifera (L.) Dunal adventitious roots and withanolide A production. Nat. Prod. Res. 2013, 27, 185-189. [CrossRef] [PubMed]

86. Ho, T.T.; Lee, K.J.; Lee, J.D.; Bhushan, S.; Paek, K.Y.; Park, S.Y. Adventitious root culture of Polygonum multiflorum for phenolic compounds and its pilot-scale production in 500 L-tank. Plant Cell Tissue Organ Cult. 2017, 130, 167-181. [CrossRef]

87. Ho, T.T.; Le, K.C.; Kim, S.W.; Park, S.Y. Culture condition optimization and FT-IR analysis of Polygonum multiflorum Thunb adventitious root cultures grown in an air-lift bioreactor system. Plant Cell Tissue Organ Cult. 2021, 144, 371-381.

88. Ho, T.T.; Lee, J.D.; Jeong, C.S.; Paek, K.Y.; Park, S.Y. Improvement of biosynthesis and accumulation of bioactive compounds by elicitation in adventitious root cultures of Polygonum multiflorum. Appl. Microbiol. Biotechnol. 2018, 102, 199-209. [CrossRef]

89. Thiruvengadam, M.; Praveen, N.; Kim, E.H.; Kim, S.H.; Chung, I.M. Production of anthraquinones, phenolic compounds and biological activities from hairy root cultures of Polygonum multiflorum Thunb. Protoplasma 2014, 251, 555-566. [CrossRef]

90. Yu, Y.; Zhang, W.B.; Li, X.Y.; Piao, X.C.; Jiang, J.; Lian, M.L. Pathogenic fungal elicitors enhance ginsenoside biosynthesis of adventitious roots in Panax quinquefolius during bioreactor culture. Ind. Crop. Prod. 2016, 94, 729-735. [CrossRef]

91. Huang, B.; Lin, H.; Yan, C.; Qiu, H.; Qiu, L.; Yu, R. Optimal inductive and cultural conditions of Polygonum multiflorum transgenic hairy roots mediated with Agrobacterium rhizogenes R1601 and an analysis of their anthraquinone constituents. Pharmacogn. Mag. 2014, 10, 77.

92. Murthy, H.N.; Dijkstra, C.; Anthony, P.; White, D.A.; Davey, M.R.; Power, J.B.; Paek, K.Y. Establishment of Withania somnifera hairy root cultures for the production of withanolide A. J. Integr. Plant Biol. 2008, 50, 975-981. [CrossRef] 
93. Rajeswara Rao, B.R. Opportunities and challenges in the cultivation of Ashwagandha \{Withania somnifera (L.) Du-nal\}. J. Pharmacogn. 2012, 3, 88-91.

94. Kumar, A.; Kaul, M.K.; Bhan, M.K.; Khanna, P.K.; Suri, K.A. Morphological and chemical variation in 25 collections of the Indian medicinal plant, Withania somnifera (L.) Dunal (Solanaceae). Genet. Resour. Crop. Evol. 2007, 54, 655-660. [CrossRef]

95. Kulkarni, S.K.; Dhir, A. Withania somnifera: An Indian ginseng. Prog. Neuro-Psychopharmacol. Biol. Psychiatry 2008, 32, 1093-1105. [CrossRef] [PubMed]

96. Sharada, M.; Ahuja, A.; Vij, S.P. Applications of Biotechnology in Indian Ginseng (Ashwagandha): Progress and Prospects. In Recent Advances in Plant Biotechnology and Its Applications; IK International Pvt. Ltd.: New Delhi, India, 2008 ; pp. 645-667.

97. Mirjalili, M.H.; Moyano, E.; Bonfill, M.; Cusido, R.M.; Palazón, J. Steroidal lactones from Withania somnifera, an ancient plant for novel medicine. Molecules 2009, 14, 2373-2393. [CrossRef]

98. Singh, G.; Sharma, P.K.; Dudhe, R.; Singh, S. Biological activities of Withania somnifera. Ann. Biol. Res. 2010, 1, $56-63$.

99. Dar, N.J.; Hamid, A.; Ahmad, M. Pharmacologic overview of Withania somnifera, the Indian Ginseng. Cell. Mol. Life Sci. 2015, 72, 4445-4460. [CrossRef]

100. Jayaprakasam, B.; Zhang, Y.; Seeram, N.P.; Nair, M.G. Growth inhibition of human tumor cell lines by withanolides from Withania somnifera leaves. Life Sci. 2003, 74, 125-132. [CrossRef]

101. Kaileh, M.; Berghe, W.V.; Heyerick, A.; Horion, J.; Piette, J.; Libert, C.; Haegeman, G. Withaferin A strongly elicits IкB kinase $\beta$ hyperphosphorylation concomitant with potent inhibition of its kinase activity. J. Biol. Chem. 2007, 282, 4253-4264. [CrossRef]

102. Sivanandhan, G.; Arun, M.; Mayavan, S.; Rajesh, M.; Jeyaraj, M.; Dev, G.K.; Ganapathi, A. Optimization of elicitation conditions with methyl jasmonate and salicylic acid to improve the productivity of withanolides in the adventitious root culture of Withania somnifera (L.) Dunal. Appl. Biochem. Biotechnol. 2012, 168, 681-696. [CrossRef]

103. Dhar, R.S.; Verma, V.; Suri, K.A.; Sangwan, R.S.; Satti, N.K.; Kumar, A.; Qazi, G.N. Phytochemical and genetic analysis in selected chemotypes of Withania somnifera. Phytochemistry 2006, 67, 2269-2276. [CrossRef]

104. Praveen, N.; Murthy, H.N. Production of withanolide-A from adventitious root cultures of Withania somnifera. Acta Physiol. Plant. 2010, 32, 1017-1022. [CrossRef]

105. Rangaraju, S.; Lokesha, A.N.; Aswath, C.R. Improved production of withanolides in adventitious root cultures of Withania somnifera by suspension culture method. Biosci. Biotech. Res. Comm. 2019, 12, 73-79.

106. Rani, G.; Arora, S.; Nagpal, A. Direct rhizogenesis from in vitro leaves of Withania somnifera (L.) Dunal. J. Herbs Spices Med. Plants 2003, 10, 47-54. [CrossRef]

107. Sivanandhan, G.; Arun, M.; Mayavan, S.; Rajesh, M.; Mariashibu, T.S.; Manickavasagam, M.; Ganapathi, A. Chitosan enhances withanolides production in adventitious root cultures of Withania somnifera (L.) Dunal. Ind. Crop. Prod. 2012, 37, 124-129. [CrossRef]

108. Praveen, N.; Murthy, H.N. Synthesis of withanolide A depends on carbon source and medium pH in hairy root cultures of Withania somnifera. Ind. Crop. Prod. 2012, 35, 241-243. [CrossRef]

109. Pandey, H.; Pandey, P.; Pandey, S.S.; Singh, S.; Banerjee, S. Meeting the challenge of stevioside production in the hairy roots of Stevia rebaudiana by probing the underlying process. Plant Cell Tissue Organ Cult. 2016, 126, 511-521. [CrossRef]

110. Sivanandhan, G.; Dev, G.K.; Jeyaraj, M.; Rajesh, M.; Arjunan, A.; Muthuselvam, M.; Ganapathi, A. Increased production of withanolide A, withanone, and withaferin A in hairy root cultures of Withania somnifera (L.) Dunal elicited with methyl jasmonate and salicylic acid. Plant Cell Tissue Organ Cult. 2013, 114, 121-129. [CrossRef]

111. Thilip, C.; Mehaboob, V.M.; Varutharaju, K.; Faizal, K.; Raja, P.; Aslam, A.; Shajahan, A. Elicitation of withaferin-A in hairy root culture of Withania somnifera (L.) Dunal using natural polysaccharides. Biologia 2019, 74, 961-968.

112. Abbasi, B.H.; Saxena, P.K.; Murch, S.J.; Liu, C.Z. Echinacea biotechnology: Challenges and opportunities. Vitr. Cell. Dev. Biol.-Plant 2007, 43, 481-492. [CrossRef]

113. Oláh, A.; Szabó-Papp, J.; Soeberdt, M.; Knie, U.; Dähnhardt-Pfeiffer, S.; Abels, C.; Bíró, T. Echinacea purpurea-derived alkylamides exhibit potent anti-inflammatory effects and alleviate clinical symptoms of atopic eczema. J. Dermatol. Sci. 2017, 88, 67-77. [CrossRef] [PubMed]

114. Jeong, J.A.; Wu, C.H.; Murthy, H.N.; Hahn, E.J.; Paek, K.Y. Application of an airlift bioreactor system for the production of adventitious root biomass and caffeic acid derivatives of Echinacea purpurea. Biotechnol. Bioprocess Eng. 2009, 14, 91-98. [CrossRef]

115. Demirci, T.; Akçay, U.Ç.; Baydar, N.G. Effects of 24-epibrassinolide and 1-phenylalanine on growth and caffeic acid derivative production in hairy root culture of Echinacea purpurea L. Moench. Acta Physiol. Plant. 2020, 42, 1-11. [CrossRef]

116. Wang, B.; Zhang, G.; Zhu, L.; Chen, L.; Zhang, Y. Genetic transformation of Echinacea purpurea with Agrobacterium rhizogenes and bioactive ingredient analysis in transformed cultures. Colloids Surf. B Biointerfaces 2006, 53, 101-104. [CrossRef] [PubMed]

117. Kết, N.V.; Anh, T.T.L. ẢNH HƯỞNG CỦA HÀM LƯợNG KHOÁNG ĐA LƯợNG VÀ BỔ SUNG DINH DƯỠNG VÀO GIAI ĐOẠN SAU CỦA QUÁ TRİNH NUÔI CÂYY ĐẾN SỰ SINH TRƯỞNG HUYỀN PHÙ TỂ BÀO SÂM NGỌC LINH. Tạp Chí Khoa Học Đại Học Đà Lạt 2017, 6, 419-430. [CrossRef]

118. Demirci, T.; Akçay, U.Ç.; Baydar, N.G. Physical and biochemical differences in Agrobacterium rhizogenes-mediated transgenic hairy root lines of Echinacea purpurea. Vitr. Cell. Dev. Biol.-Plant 2020, 56, 875-881. [CrossRef]

119. Abdoli, M.; Mehrpooya, Z.; Talebian, M.R. Effect of salicylic acid and yeast extract on caffeic acid derivatives production in Echinacea purpurea L. J. Med. Plants 2021, 20, 36-47. [CrossRef] 
120. Murthy, H.N.; Dalawai, D.; Bhat, M.A.; Dandin, V.S.; Paek, K.Y.; Park, S.Y. Biotechnological Production of Useful Phytochemicals from Adventitious Root Cultures. In Plant Cell and Tissue Differentiation and Secondary Metabolites: Fundamentals and Applications; Springer: Berlin/Heidelberg, Germany, 2021; pp. 469-485.

121. Aboseidah, A.A.; El-hamahmy, A.E.; Abo-Elsoud, I.; Ali, E.M. Effect of UV-C Radiation on Egyptian Henbane (Hyoscyamus muticus L.) Callus Growth and Biochemical Components. Hortscience J. Suez Canal Univ. 2019, 8, 11-21. [CrossRef]

122. Mehrotra, S.; Mishra, S.; Srivastava, V. Hairy Roots Biotechnology Unzipped: A Journey of Reality and Promises. In Hairy Root Cultures Based Applications; Springer: Berlin/Heidelberg, Germany, 2020; pp. 1-10.

123. Ali, H.; Khan, M.A.; Kayani, W.K.; Dilshad, E.; Rani, R.; Khan, R.S. Production of biomass and medicinal metabolites through adventitious roots in Ajuga bracteosa under different spectral lights. J. Photochem. Photobiol. B Biol. 2019, 193, 109-117. [CrossRef]

124. Hafeez, K.; Andleeb, S.; Ghousa, T.G.; Mustafa, R.; Naseer, A.; Shafique, I.; Akhter, K. Phytochemical screening, alpha-glucosidase inhibition, antibacterial and antioxidant potential of Ajuga bracteosa extracts. Curr. Pharm. Biotechnol. 2017, 18, 336-342. [CrossRef]

125. Imran, M.; Jan, H.; Faisal, S.; Shah, S.A.; Shah, S.; Khan, M.N.; Syed, S. In vitro examination of anti-parasitic, anti-Alzheimer, insecticidal and cytotoxic potential of Ajuga bracteosa Wallich leaves extracts. Saudi J. Biol. Sci. 2021, 28, 3031-3036. [CrossRef] [PubMed]

126. Ali, H.; Khan, M.A.; Ullah, N.; Khan, R.S. Impacts of hormonal elicitors and photoperiod regimes on elicitation of bioactive secondary volatiles in cell cultures of Ajuga bracteosa. J. Photochem. Photobiol. B Biol. 2018, 183, 242-250. [CrossRef] [PubMed]

127. Kayani, W.K.; Hasan, H.; Mirza, B. Advances in Genetic Engineering of Ajuga Species. In Biotechnological Approaches for Medicinal and Aromatic Plants; Springer: Berlin/Heidelberg, Germany, 2018; pp. 599-629.

128. Rodrigues, V.; Kumar, A.; Prabhu, K.N.; Pragadheesh, V.S.; Shukla, A.K.; Sundaresan, V. Adventitious root cultures of Decalepis salicifolia for the production of 2-hydroxy-4-methoxybenzaldehyde, a vanillin isomer flavor metabolite. Appl. Microbiol. Biotechnol. 2021, 105, 3087-3099. [CrossRef] [PubMed]

129. Nabi, N.; Singh, S.; Saffeullah, P. Responses of in vitro cell cultures to elicitation: Regulatory role of jasmonic acid and methyl jasmonate: A review. Vitr. Cell. Dev. Biol.-Plant 2021, 57, 341-355. [CrossRef]

130. Khan, M.A.; Ali, A.; Mohammad, S.; Ali, H.; Khan, T.; Jan, A.; Ahmad, P. Iron nano modulated growth and biosynthesis of steviol glycosides in Stevia rebaudiana. Plant Cell Tissue Organ Cult. 2020, 143, 121-130. [CrossRef]

131. Liu, P.; Zhao, H.; Luo, Y. Anti-aging implications of Astragalus membranaceus (Huangqi): A well-known Chinese tonic. Aging Dis. 2017, 8, 868. [CrossRef]

132. Sun, H.; Gao, H.; Zhang, C.; Cao, Q. Enhanced production of calycosin-7-O- $\beta$-D-glucoside and astragaloside IV from adventitious root cultures of Astragalus membranaceus var. mongholicus by green leaf volatiles. Ind. Crop. Prod. 2021, 168, 113598. [CrossRef]

133. Moola, A.K.; Kumar, T.S.; Kumari, B.R. Enhancement of Celastrol compound by silver nanoparticles and acetosyringone in Celastrus paniculatus Willd. through adventitious and hairy root culture. J. Plant Biochem. Biotechnol. 2021, 56, 1-6. [CrossRef]

134. Lee, R.X.; Hassan, Z.; Subramaniam, S.; Chew, B.L. Adventitious root cultures of Clitoria ternatea L. and its potential as a memory enhancer alternative. Plant Biotechnol. Rep. 2021, 15, 163-176. [CrossRef]

135. Feng, Y.; Zhao, Y.; Ha, Y.; Li, J.; Su, Z.; Quan, X.; Wu, W. Drought stress-induced methyl jasmonate accumulation promotes calycosin-7-O- $\beta$-d-glucoside production in Astragalus membranaceus adventitious roots. Plant Cell Tissue Organ Cult. 2021, 147, 561-568. [CrossRef]

136. Swamy, M.K.; Paramashivaiah, S.; Hiremath, L.; Akhtar, M.S.; Sinniah, U.R. Micropropagation and Conservation of Selected Endangered Anticancer Medicinal Plants from the Western Ghats of India. In Anticancer Plants: Natural Products and Biotechnological Implements; Springer: Berlin/Heidelberg, Germany, 2018; pp. 481-505.

137. Gao, Y.; Wu, C.H.; Piao, X.C.; Han, L.; Gao, R.; Lian, M.L. Optimization of culture medium components and culture period for production of adventitious roots of Echinacea pallida (Nutt.) Nutt. Plant Cell Tissue Organ Cult. 2018, 135, 299-307. [CrossRef]

138. Fan, M.Z.; An, X.L.; Cui, X.H.; Jiang, X.L.; Piao, X.C.; Jin, M.Y.; Lian, M.L. Production of eurycomanone and polysaccharides through adventitious root culture of Eurycoma longifolia in a bioreactor. Biochem. Eng. J. 2021, 171, 108013. [CrossRef]

139. Khan, T.; Ali, M.; Khan, A.; Nisar, P.; Jan, S.A.; Afridi, S.; Shinwari, Z.K. Anticancer plants: A review of the active phytochemicals, applications in animal models, and regulatory aspects. Biomolecules 2020, 10, 47. [CrossRef] [PubMed]

140. Hao, N.; Piao, Z.; Zang, J.; Li, H.; Zhou, R. Establishment of adventitious root cultures and assessment of secoiridoid production in the Chinese medicinal plant Gentiana scabra. Vitr. Cell. Dev. Biol.-Plant 2021, 57, 864-873. [CrossRef]

141. Eid, A.M.; Fouda, A.; Abdel-Rahman, M.A.; Salem, S.S.; Elsaied, A.; Oelmüller, R.; Hassan, S.E.D. Harnessing Bacterial Endophytes for Promotion of Plant. Growth and Biotechnological Applications: An Overview. Plants 2021, 10, 935. [CrossRef] [PubMed]

142. Kusuma, D.Y.; Kristanti, A.N.; Manuhara, Y.S.W. Effect of sucrose and immersion frequency on production of adventitious roots and secondary metabolites of Gynura procumbens (Lour.) Merr in temporary immersion bioreactors. Asian J. Plant Sci. 2017, 16, 24-36.

143. Kusuma, D.Y.; Kristanti, A.N.; Wibowo, A.T.; Chin, T.B.; Manuhara, Y.S.W. Aeration Volume and Inoculum Density Using in Bioreactor to Optimized Biomass Production and Secondary Metabolites in Gynura procumbens (Lour.) Merr. Adventitious Roots Culture. Syst. Rev. Pharm. 2021, 12, 102-112.

144. Sathish, S.; Vasudevan, V.; Karthik, S.; Elayaraja, D.; Pavan, G.; Ajithan, C.; Manickavasagam, M. Elicitors induced 1-Dopa accumulation in adventitious root cultures of Hybanthus enneaspermus (L.) F. Muell. Vegetos 2020, 33, 304-312. [CrossRef] 
145. Sobhani Najafabadi, A.; Khanahmadi, M.; Ebrahimi, M.; Moradi, K.; Behroozi, P.; Noormohammadi, N. Effect of different quality of light on growth and production of secondary metabolites in adventitious root cultivation of Hypericum perforatum. Plant Signal. Behav. 2019, 14, 1640561. [CrossRef]

146. Kannan, N.; Manokari, M.; Shekhawat, M.S. Enhanced production of anthraquinones and phenolic compounds using chitosan from the adventitious roots of Morinda coreia Buck and Ham. Ind. Crop. Prod. 2020, 148, 112321. [CrossRef]

147. Krishnan, S.S.; Siril, E. Elicitor mediated adventitious root culture for the large-scale production of anthraquinones from Oldenlandia umbellata L. Ind. Crop. Prod. 2018, 114, 173-179. [CrossRef]

148. Jiang, X.L.; Piao, X.C.; Gao, R.; Jin, M.Y.; Jiang, J.; Jin, X.H.; Lian, M.L. Improvement of bioactive compound accumulation in adventitious root cultures of an endangered plant species, Oplopanax elatus. Acta Physiol. Plant. 2017, 39, 1-10. [CrossRef]

149. Han, L.; Piao, X.C.; Jiang, J.; Jiang, X.L.; Yin, C.R.; Lian, M.L. A high production of flavonoids and anthraquinones via adventitious root culture of Oplopanax elatus and evaluating antioxidant activity. Plant Cell Tissue Organ Cult. 2019, 137, 173-179. [CrossRef]

150. Hao, Y.J.; An, X.L.; Sun, H.D.; Piao, X.C.; Gao, R.; Lian, M.L. Ginsenoside synthesis of adventitious roots in Panax ginseng is promoted by fungal suspension homogenate of Alternaria panax and regulated by several signaling molecules. Ind. Crop. Prod. 2020, 150, 112414. [CrossRef]

151. Linh, N.T.N.; Tam, H.T.; Tung, H.T.; Luan, V.Q.; Hien, V.T.; Loc, N.H.; Nhut, D.T. Improvement of bioactive saponin accumulation in adventitious root cultures of Panax vietnamensis via culture periods and elicitation. Plant Cell Tissue Organ Cult. 2019, 137, 101-113. [CrossRef]

152. Ebrahimi, S.; Zaker, A.; Abrishamchi, P.; Bahrami, A.R.; Ganjeali, A.; Sodagar, N. Hairy root induction and secondary metabolite production in Perovskia abrotanoides Karel. J. Plant Process. Funct. 2017, 6, 17-26.

153. Jaisi, A.; Panichayupakaranant, P. Chitosan elicitation and sequential Diaion ${ }^{\circledR H P}-20$ addition a powerful approach for enhanced plumbagin production in Plumbago indica root cultures. Process. Biochem. 2017, 53, 210-215. [CrossRef]

154. Zhang, B.; Chen, L.; Huo, Y.; Zhang, J.; Zhu, C.; Zhang, X.; Ma, Z. Establishment of adventitious root cultures from leaf explants of Tripterygium wilfordii (thunder god vine) for the production of celastrol. Ind. Crop. Prod. 2020, 155, 112834. [CrossRef]

155. Fazal, H.; Abbasi, B.H.; Ahmad, N.; Ali, M.; Shujait Ali, S.; Khan, A.; Wei, D.Q. Sustainable production of biomass and industrially important secondary metabolites in cell cultures of selfheal (Prunella vulgaris L.) elicited by silver and gold nanoparticles. Artif. Cells Nanomed. Biotechnol. 2019, 47, 2553-2561. [CrossRef]

156. Ahmad, A.; Ali, H.; Khan, H.; Begam, A.; Khan, S.; Ali, S.S.; Abbasi, B.H. Effect of gibberellic acid on production of biomass, polyphenolics and steviol glycosides in adventitious root cultures of Stevia rebaudiana (Bert.). Plants 2020, 9, 420. [CrossRef]

157. Faizal, A.; Sari, A.V. Enhancement of saponin accumulation in adventitious root culture of Javanese ginseng (Talinum paniculatum Gaertn.) through methyl jasmonate and salicylic acid elicitation. Afr. J. Biotechnol. 2019, 18, 130-135.

158. Zhang, B.; Chen, M.; Pu, S.; Chen, L.; Zhang, X.; Zhang, J.; Zhu, C. Identification of secondary metabolites in Tripterygium wilfordii hairy roots and culture optimization for enhancing wilforgine and wilforine production. Ind. Crop. Prod. 2020, $148,112276$. [CrossRef]

159. Sivanandhan, G.; Selvaraj, N.; Ganapathi, A.; Lim, Y.P. Withanolide Production in Hairy Root Culture of Withania somnifera (L.) Dunal: A Review. In Plant Cell and Tissue Differentiation and Secondary Metabolites: Fundamentals and Applications; Springer: Berlin/Heidelberg, Germany, 2021; pp. 607-624.

160. Zhai, X.; Luo, D.; Li, X.; Han, T.; Jia, M.; Kong, Z.; Zheng, C. Endophyte Chaetomium globosum D38 promotes bioactive constituents accumulation and root production in Salvia miltiorrhiza. Front. Microbiol. 2018, 8, 2694. [CrossRef] [PubMed]

161. Gai, Q.Y.; Jiao, J.; Wang, X.; Liu, J.; Wang, Z.Y.; Fu, Y.J. Chitosan promoting formononetin and calycosin accumulation in Astragalus membranaceus hairy root cultures via mitogen-activated protein kinase signaling cascades. Sci. Rep. 2019, 9, 1-11. [CrossRef]

162. Nazirah, A.; Nor-Hasnida, H.; Ismanizan, I.; Norlia, B.; Abdul-Rashih, A.; Muhammad-Fuad, Y.; Mohd-Saifuldullah, A.W. Production of 9-methoxycanthin-6-one in elicited Eurycoma longifolia hairy root. J. Trop. For. Sci. 2018, 30, 606-614. [CrossRef]

163. Srivastava, M.; Singh, G.; Sharma, S.; Shukla, S.; Misra, P. Elicitation enhanced the yield of glycyrrhizin and antioxidant activities in hairy root cultures of Glycyrrhiza glabra L. J. Plant Growth Regul. 2019, 38, 373-384. [CrossRef] [PubMed]

164. Desmet, S.; Dhooghe, E.; De Keyser, E.; Van Huylenbroeck, J.; Müller, R.; Geelen, D.; Lütken, H. Rhizogenic agrobacteria as an innovative tool for plant breeding: Current achievements and limitations. Appl. Microbiol. Biotechnol. 2020, 104, $2435-2451$. [CrossRef]

165. Murthy, H.N.; Park, S.Y.; Paek, K.Y. Production of Ginsenosides by Hairy Root Cultures of Panax ginseng. In Production of Plant Derived Natural Compounds through Hairy Root Culture; Springer: Cham, Switzerland, 2017; pp. 203-216.

166. Kochan, E.; Szymczyk, P.; Kuźma, Ł.; Lipert, A.; Szymańska, G. Yeast extract stimulates ginsenoside production in hairy root cultures of American ginseng cultivated in shake flasks and nutrient sprinkle bioreactors. Molecules 2017, 22, 880. [CrossRef]

167. Gantait, S.; Mitra, M.; Chen, J.-T. Biotechnological interventions for ginsenosides production. Biomolecules 2020, 10, 538. [CrossRef]

168. Dhiman, N.; Patial, V.; Bhattacharya, A. The Current Status and Future Applications of Hairy Root Cultures. In Biotechnological Approaches for Medicinal and Aromatic Plants; Springer: Berlin/Heidelberg, Germany, 2018; pp. 87-155.

169. Vergara-Martínez, V.M.; Estrada-Soto, S.E.; Valencia-Díaz, S.; Garcia-Sosa, K.; Peña-Rodríguez, L.M.; de Jesús Arellano-García, J.; Perea-Arango, I. Methyl jasmonate enhances ursolic, oleanolic and rosmarinic acid production and sucrose induced biomass accumulation, in hairy roots of Lepechinia caulescens. PeerJ 2021, 9, e11279. [CrossRef]

170. Pandey, V.; Ansari, W.A.; Misra, P.; Atri, N. Withania somnifera: Advances and implementation of molecular and tissue culture techniques to enhance its application. Front. Plant Sci. 2017, 8, 1390. [CrossRef] 
171. Saadah, I.N.; Kristanti, A.N.; Hardjo, P.H.; Manuhara, Y.S.W. Shoots Culture of Gynura procumbens (Lour.) Merr. in Balloon-Type Bubble-Bioreactor Influenced by Sucrose Concentration and Inoculums Density. Asian J. Plant Sci. 2019, 18, 85-90. [CrossRef]

172. Shuang, Z.; Hong, T. Enhanced production of valtrate in hairy root cultures of Valeriana jatamansi Jones by methyl jasmonate, jasmonic acid and salicylic acid elicitors. Not. Bot. Horti Agrobot. Cluj-Napoca 2020, 48, 839-848.

173. Yousefian, Z.; Hosseini, B.; Rezadoost, H.; Palazón, J.; Mirjalili, M.H. Production of the anticancer compound withaferin a from genetically transformed hairy root cultures of Withania somnifera. Nat. Prod. Commun. 2018, 13, 1934578X1801300806. [CrossRef] 